\title{
Biology and Molecular Pathogenesis of Mature T-Cell Lymphomas
}

\author{
José R. Cortés ${ }^{1}$ and Teresa Palomero ${ }^{1,2}$ \\ ${ }^{1}$ Institute for Cancer Genetics, ${ }^{2}$ Department of Pathology and Cell Biology, Columbia University \\ Irving Medical Center, New York, New York 10032, USA \\ Correspondence: tp2151@columbia.edu
}

Peripheral T-cell lymphomas (PTCLs) constitute a highly heterogeneous group of hematological diseases with complex clinical and molecular features consistent with the diversity of the T-cell type from which they originate. In the past several years, the systematic implementation of high-throughput genomic technologies for the analysis of T-cell malignancies has supported an exponential progress in our understanding of the genetic drivers of oncogenesis and unraveled the molecular complexity of these diseases. Recent findings have helped redefine the classification of T-cell malignancies and provided novel biomarkers to improve diagnosis accuracy and analyze the response to therapy. In addition, multiple novel targeted therapies including small-molecule inhibitors, antibody-based approaches, and immunotherapy have shown promising results in early clinical analysis and have the potential to completely change the way T-cell malignancies have been treated traditionally.

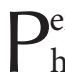
eripheral T-cell lymphomas (PTCLs) are a heterogeneous group of highly aggressive malignant hematologic tumors that arise from clonal proliferation of mature post-thymic T cells (Gaulard and de Leval 2014). PTCLs account for $\sim 15 \%$ of all non-Hodgkin lymphomas and cover almost 30 different entities (Swerdlow et al. 2016). Compared with B-cell lymphomas, PTCLs are less common, are more difficult to diagnose and classify, are more aggressive, and have inferior outcomes with current treatments. Indeed, with rare exceptions, the prognosis for PTCL is dismal, with survival rates in the $20 \%-$ $30 \%$ range at 5 years (Savage 2008). T-cell lym- phomas are also less understood in terms of their normal T-cell counterparts, and until recently, most subtypes lacked defined drivers that could potentially be targeted for the development of precision therapies. Interestingly, the incidence of PTCL, which generally affects the elderly population, has been consistently increasing over the past decades, but unfortunately, this increase has not been accompanied by improvements in survival (Weisenburger et al. 2011).

However, over the past few years, genomic and transcriptomic studies have substantially advanced our understanding of the molecular subtyping of PTCL and facilitated the identifi-

Editors: Michael G. Kharas, Ross L. Levine, and Ari M. Melnick

Additional Perspectives on Leukemia and Lymphoma: Molecular and Therapeutic Insights available at

www.perspectivesinmedicine.org

Copyright (C) 2021 Cold Spring Harbor Laboratory Press; all rights reserved; doi: 10.1101/cshperspect.a035402

Cite this article as Cold Spring Harb Perspect Med 2021;11:a035402 
J.R. Cortés and T. Palomero

cation of molecular vulnerabilities in these tumors, opening the field for the development of tailored therapies targeting specific driver genetic alterations that will hopefully be translated into better clinical outcomes.

\section{CLASSIFICATION AND MOLECULAR ETIOLOGY OF T-CELL LYMPHOMA}

The fourth edition of the World Health Organization (WHO) classification established the guidelines for classification of hematopoietic and lymphoid tumors in 2008 , with a major revision published in 2016 primarily to address several major advances in the field with significant clinical and biological implications in patient management (Swerdlow et al. 2016). Many of these changes are the result of genomic studies, including analysis of Gene Expression Profile (GEP) and characterization of the genetic landscape of T-cell and natural killer (NK)-cell neoplasms. This revised classification of the lymphoid neoplasms included the addition of a number of provisional entities highlighted in Table 1. In this review, we will describe the most frequent subtypes of PTCL, as well as the most common genetic aberrations identified for each subgroup.

Table 1. Classification of mature T and NK neoplasms according to WHO 2016 revision

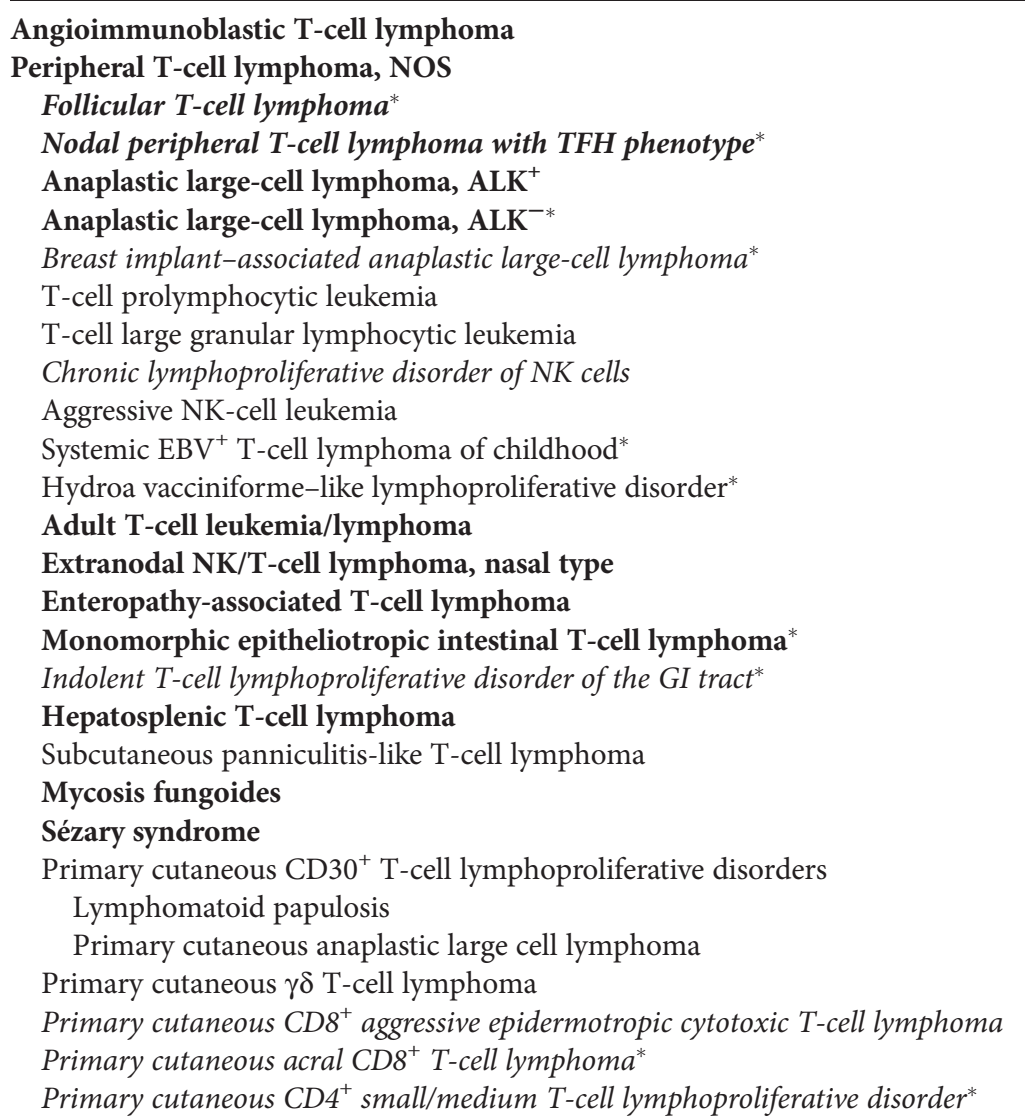

Data adapted from Swerdlow et al. 2016.

Provisional entities are listed in italics and changes from the 2008 classification are indicated by asterisks $\left({ }^{*}\right)$. Entities that will be discussed in this review are shown in bold.

(NK) Natural killer, (NOS) not otherwise specified, (TFH) T-follicular helper, (ALK) anaplastic lymphoma kinase, (EBV) Epstein-Barr virus, (GI) gastrointestinal. 


\section{ANGIOIMMUNOBLASTIC T-CELL LYMPHOMA}

Angioimmunoblastic T-cell lymphoma (AITL) is the second most common PTCL subtype worldwide and the most frequent subtype in the Western world, where it represents $>30 \%$ of PTCL cases (Federico et al. 2013). AITL develops with a unique pathobiology and clinical presentation including a chronically activated immune system with frequent hypergammaglobulinemia and autoimmune features (Lunning and Vose 2017). AITL is characterized by the presence of clonal $\mathrm{CD}^{+}{ }^{+}$neoplastic $\mathrm{T}$ cells, a highly reactive tumor microenvironment, and clonal expansions affecting the B-cell compartment, frequently positive for Epstein-Barr virus (EBV) (Zhou et al. 2007). Initial gene expression profiling studies contributed to establish $\mathrm{T}$ follicular helper (TFH) cells as the cell of origin in AITL (de Leval et al. 2007), based on a characteristic expression of TFH markers in the malignant $\mathrm{T}$ cells. Indeed, the differential diagnosis criteria for AITL requires the concurrent presence of at least two TFH markers, including PD1, CXCR5, ICOS, BCL6, CXCL13, CD10, and SAP, to confirm the diagnosis of AITL.

Genetic alterations affecting epigenetic regulators, including TET2, DNMT3A, and IDH2, are one of the hallmarks of AITL (Cortés and Palomero 2016). The ten-eleven translocation 2 (TET2) encodes a 2 -oxoglutarate/Fe $2^{+}$-dependent oxygenase that participates in the epigenetic control of gene expression by catalyzing the oxidation of DNA 5-methylcytosine to 5-hydroxymethylcytosine (Tahiliani et al. 2009; Ito et al. 2010; Cimmino et al. 2011). First identified as a tumor suppressor in myeloid malignancies (Abdel-Wahab et al. 2009; Delhommeau et al. 2009), multiple studies have shown a high prevalence of loss-of-function mutations in TET2 in PTCLs particularly in AITL $(\sim 50 \%)$ and PTCLnot otherwise specified (NOS) ( 40\%), in which they are frequently identified as an initial event in the process of transformation (Couronné et al. 2012; Palomero et al. 2014; Sakata-Yanagimoto et al. 2014; Yoo et al. 2014) and are associated with worse outcome (Lemonnier et al. 2012). In a recent study, analysis of TET2 mu- tations and TCR rearrangements in AITL and PTCL-NOS cases demonstrated the presence of biclonal populations derived from a common TET2 mutant progenitor, suggestive of parallel tumor evolution from common hematopoietic progenitor pool (Yao et al. 2020). Loss of Tet2 has been associated with enhanced hematopoietic stem cell (HSC) self-renewal and an increased HSC pool (Moran-Crusio et al. 2011). Moreover, TET2 mutations are frequently found in the blood of healthy elderly individuals, a condition termed clonal hematopoiesis of indeterminate potential (CHIP), and are associated with increased risk for developing a hematologic malignancy (Busque et al. 2012; Steensma 2018; Steensma and Ebert 2020). The relative high frequency of clonal hematopoiesis in otherwise healthy individuals indicates that these initial TET2 mutations are not sufficient for transformation; however, mutant premalignant cells can fully transform into diverse malignancies upon acquisition of secondary genetic hits.

DNMT3A encodes a DNA methyltransferase that controls cytosine methylation and is recurrently affected by loss-of-function mutations in $10 \%-40 \%$ of AITL patients. Mutations in DNMT3A are considered an initial event in the process of transformation and interestingly frequently co-occur with TET2 mutations (Cortés and Palomero 2016). Indeed, cooperation between loss-of-function mutations in Dnmt3a and Tet 2 has been shown to lead to malignant transformation in mouse models (Scourzic et al. 2016).

Finally, IDH2 is a metabolic mitochondrial enzyme involved in the generation of 2-oxoglutarate that is specifically mutated in $30 \%-40 \%$ of AITL patients (Cortés and Palomero 2016). Mutant IDH2 forms have a neomorphic enzymatic activity leading instead to the generation of 2-hydroxyglutarate, an oncometabolite that antagonizes the activity the TET family of enzymes (Cortés and Palomero 2016). AITL is the only PTCL subgroup in which IDH2 mutations are found, and, remarkably, they occur almost exclusively in position R172 (R172K, R172S) (Cairns et al. 2012), which is associated with increased production of 2-HG compared to other IDH2 mutant alleles. Although mutations in 
J.R. Cortés and T. Palomero

TET2 and IDH2 are also present in myeloid malignancies, where they are mutually exclusive, AITLs frequently present co-occurring mutations in IDH2 and TET2 (Cortés and Palomero 2016). Interestingly, IDH2 mutations in AITL are presumed to constitute a secondary hit and might refine the differentiation of the premalignant clones. Indeed, the co-occurrence of TET2 inactivation and IDH2 mutations is associated with a potential cooperative effect in the regulation of the expression of TFH specific genes, leading to a more polarized TFH signature than achieved by the presence of TET2 mutations alone (Wang et al. 2015a).

Gene expression profiling studies have proposed that AITL tumors may be driven by increased T-cell receptor signaling. Consistently, genomic studies have uncovered the presence of highly recurrent mutations affecting T-cell receptor-initiated signaling pathways, including the frequent mutations in the small GTPase $R H O A$, as well as genetic alterations affecting VAV1, PLCG1, CD28, and the tyrosine kinase FYN (Vallois et al. 2016).

A central role of RHOA in the pathogenesis of AITL is supported by the identification of a recurrent, highly prevalent heterozygous missense RHOA G17V mutation detected in up to $70 \%$ of the patients with AITLs (Fig. 1; Palomero et al. 2014; Sakata-Yanagimoto et al. 2014; Yoo et al. 2014). The presence of the RHOA G17V mutation is highly specific of AITL and has become a molecular diagnostic determinant for this PTCL subgroup. Clinical studies have even suggested that the presence of RHOA G17V could be associated with worse prognosis (Nagao et al. 2016; Ondrejka et al. 2016). Mutations in RHOA G17V generally co-occur with mutations in epigenetic regulators, being most frequently associated with loss-offunction mutations in TET2. Mutations in

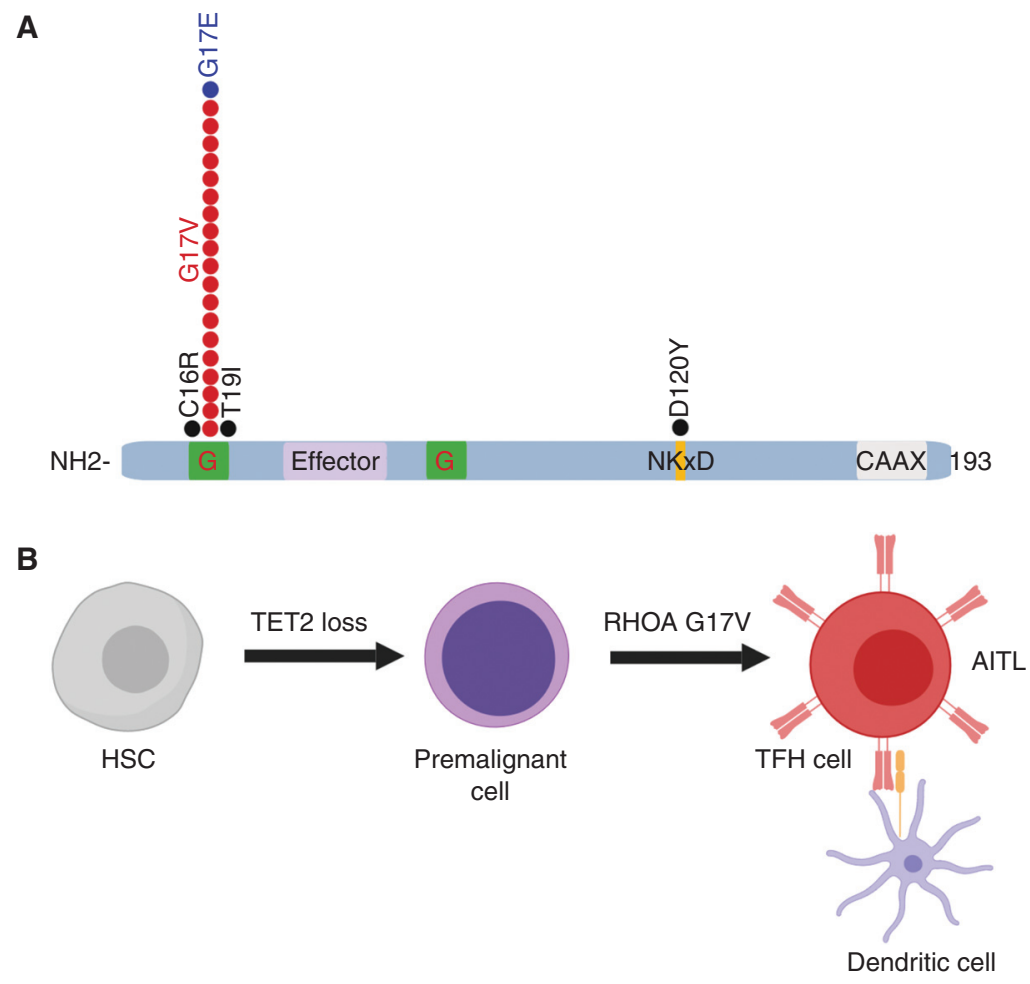

Figure 1. Schematic $(A)$ representation of the RHOA mutations identified in AITL and model for process of malignant transformation leading to AITL (B). (A, Adapted from Palomero et al. 2014, courtesy of Springer/ Nature (C) 2014; $B$, adapted from Cortés et al. 2018, with permission from Elsevier @ 2018 .) 
RHOA G17V act as dominant negatives interfering with the signaling initiated by wild-type RHOA (Palomero et al. 2014). Recent studies using engineered mouse models demonstrated that expression of Rhoa G17V in $\mathrm{CD}^{+}{ }^{+} \mathrm{T}$ cells induces increased proliferation and $\mathrm{TFH}$-cell specification (Cortés et al. 2018; $\mathrm{Ng}$ et al. 2018). Notably, the combination of Tet2 loss and expression of Rhoa G17V is sufficient to induce AITL development (Cortés et al. 2018). This result supports a multistep model for AITL development in which loss-of-function mutations in epigenetics factors in early hematopoietic progenitors will be an initiating event in the process of transformation, inducing the generation of multipotent premalignant clones. Upon acquisition of a second hit in RHOA G17V, premalignant cells differentiate toward TFH cells and induce development of AITL (Fig. 1). Both TFH lineage specification and AITL development downstream of RHOA G17V depend on the activation of the ICOS/PI3K/mTOR signaling pathway and are sensitive to PI3K inhibitors (Cortés et al. 2018).

Mutations in VAV1 have been identified in up to $10 \%$ of AITL and PTCL-NOS patients. VAV1 encodes a hematopoietic-specific Rho family-specific guanine exchange factor (Bustelo 2000). Genomic alterations in VAV1 in PTCL include a recurrent in-frame deletion mutation (VAV1 $\triangle 778-786$ ) generated by alternative splicing mechanism as well as multiple VAV1 gene fusions affecting the carboxy-terminal domain of VAV1 that lead to its constitutive activation (Abate et al. 2017). Alterations in RHOA and VAV1 are mutually exclusive, suggesting they could be affecting the same genetic pathway (Fujisawa et al. 2018).

Recurrent mutations in $C D 28$, a major costimulatory molecule for the $\mathrm{T}$-cell receptor (TCR), have also been described in AITL (Rohr et al. 2015). PTCL-associated CD28 mutations affect the D124 and T195 residues and increase ligand-receptor interaction and signal transduction. Notably, CD28-mutated AITL patients have inferior survival compared to nonmutated cases (Rohr et al. 2015). Finally, recurrent activating mutations in FYN, a SRC family kinase, have been found in $~ 3 \%$ of PTCL-NOS and AITL cases (Palomero et al. 2014).
Similar genomic aberrations to the ones identified in AITL have been described for follicular T-cell lymphoma and nodal peripheral T-cell lymphoma with TFH phenotype (see Table 1). This has led to the grouping of these two provisional entities with AITL. All three groups share similar gene expression patterns, TFHassociated immunophenotypic markers, and genetic abnormalities; however, despite their common TFH phenotype, these diseases have differing clinical and pathological features and, as such, remain distinct entities within the classification (Swerdlow et al. 2016).

\section{PTCL-NOS}

PTCL-NOS includes mature T-cell lymphoma cases that cannot unequivocally be assigned to other subtypes, making this group highly heterogeneous and poorly understood. PTCL-NOS is the most common entity in mature T-cell neoplasms; however, the diagnosis of PTCLNOS has decreased in recent years because of the introduction of molecular profiling that allows for better lymphoma classification.

The characterization of the molecular landscape of PTCL-NOS has identified the presence of frequent mutations epigenetic regulators, including KMT2C and KMT2D, KDM6A, ARID1B, SETD1B, CREBBP and ARID2 as well as TET2 and DNMT3A, which are likely associated with the TFH-like group (Palomero et al. 2014). Also, genes involved in signaling pathways are frequent targets of alterations in PTCL-NOS, including genes in the NF- $\kappa \mathrm{B}$ and TCR signaling pathways such as TNFAIP3, APC, CHD8, ZAP70, NF1, TNFRSF14, TRAF3, and VAV1 (Palomero et al. 2014; Abate et al. 2017; Watatani et al. 2019). Recent analysis of a large PTCL-NOS cohort has identified additional altered genes, such as YTHDF2, a RNA methyl transferase, and PD-1 (Watatani et al. 2019). More interestingly, a previously undescribed molecular subtype characterized by TP53 and/or CDKN2A mutations and deletions, has been identified associated with worse prognosis, chromosomal instability, and altered immune evasion (Watatani et al. 2019), suggesting a driver role for TP53 in PTCL-NOS (Watatani et al. 2019). 
Gene expression profiling in PTCL-NOS has identified two distinct molecular subgroups characterized by the differential high expression of TBX21 or GATA3, two key regulators of Th1 and Th2 cell differentiation (Iqbal et al. 2014; Wang et al. 2015a). Although the precise mechanisms that lead to the increased expression of these master regulators are unknown, they might be related to different cells of origin. More importantly, these groups are associated with different clinical behavior and response to therapy, with expression of GATA3 being linked to worse outcome (Iqbal et al. 2014).

\section{ANAPLASTIC LARGE-CELL LYMPHOMAS}

Anaplastic large cell lymphoma (ALCL) includes several subtypes of aggressive lymphoid neoplasms with similar histologic characteristics but distinct genomic features. The latest WHO classification contains two systemic ALCL entities: $\mathrm{ALK}^{-}$ALCL and ALK ${ }^{+}$ALCL (Swerdlow et al. 2016) in addition to a primarily cutaneous form of ALCL, (cALCL), more closely related to $\mathrm{ALK}^{-} \mathrm{ALCL}$, and a new provisional category, breast implant-associated ALCL (BIALCL) (Swerdlow et al. 2016). The neoplastic cells are typically large with abundant cytoplasm and characteristic horseshoe nuclei shapes and characterized by strong expression of CD30 and negative for TCR (Shustov and Soma 2019). Despite the lack of expression of surface TCR, ALCLs are classified as T-cell lymphoma because of their peripheral presentation and the presence of TCR rearrangements that are detectable in the tumor cells at the molecular level that are supportive of a $\mathrm{T}$-cell origin. Interestingly, data from murine models suggests that transformation could be initiated in early thymocytes, before TCR $\beta$-rearrangement, and although TCR is still required for thymic egress and development of peripheral murine tumors, down-regulation of the TCR would be required to complete lymphomagenesis. This model is consistent with the characteristics of TCR rearrangements in human ALCL, which are often aberrant and would not be permissive for survival during thymic development (Malcolm et al. 2016)
$\mathrm{ALK}^{+} \mathrm{ALCL}$ is generally diagnosed in younger individuals of Western origin with slight male predominance (Ferreri et al. 2012). $\mathrm{ALK}^{+}$ ALCL constitutes also the most frequent mature aggressive lymphoma within the pediatric population. Moreover, it is also the PTCL subtype with the best overall outcome (Savage 2008). $\mathrm{ALK}^{+}$ALCL is associated with the presence of chromosomal translocations that lead to the constitutive activation of ALK, a receptor tyrosine kinase, being the most frequent $t(2 ; 5)$ translocation (nucleophosmin [NPM]-ALK). ALK translocations lead to increased activation of ERK/MAPK, JAK/STAT, and PI3K signaling pathways. Moreover, ALK fusion-mediated activation of STAT3 has been shown to be required for the maintenance of the transformed phenotype in $\mathrm{ALK}^{+}$ALCL (Chiarle et al. 2005). ALK fusions constitutively activate VAV1 and VAV3 in ALCL, increasing RAC1 and CDC42 activity, down-regulating the Wiskott-Aldrich syndrome protein (WASP) and WASP-interacting protein (WIP) tumor suppressors and promoting lymphoma survival (Choudhari et al. 2016; Menotti et al. 2019).

$\mathrm{ALK}^{-}$ALCL patients are generally older and associated with a worse outcome (Ferreri et al. 2013). Molecular events affecting DUSP22 and TP63 have been reported to be mutually exclusive and predictors of survival outcomes, with expression of DUSP22 associated with a favorable prognosis and TP63 being an unfavorable marker. Recurrent translocations and loss of TP53 and PRDM1/BLIMP1 have also been proved to have a pathogenic role associated with less favorable outcomes (Boi et al. 2013; Parrilla Castellar et al. 2014). In addition, very frequent activating mutations in the JAK/STAT pathways, more specifically in JAK1 and STAT3, have been identified in almost $20 \%$ of ALKALCL (Crescenzo et al. 2015). Recurrent gene translocations linked to JAK/STAT pathway activation, including NCOR2-ROS1, NFkB2ROS1, and different fusions affecting the TYK2 kinase, have also been identified (Crescenzo et al. 2015). This suggests that activation of STAT3 is a common mechanism of malignant transformation in ALCL, independently of ALK status, and provides a genetic rationale for the 


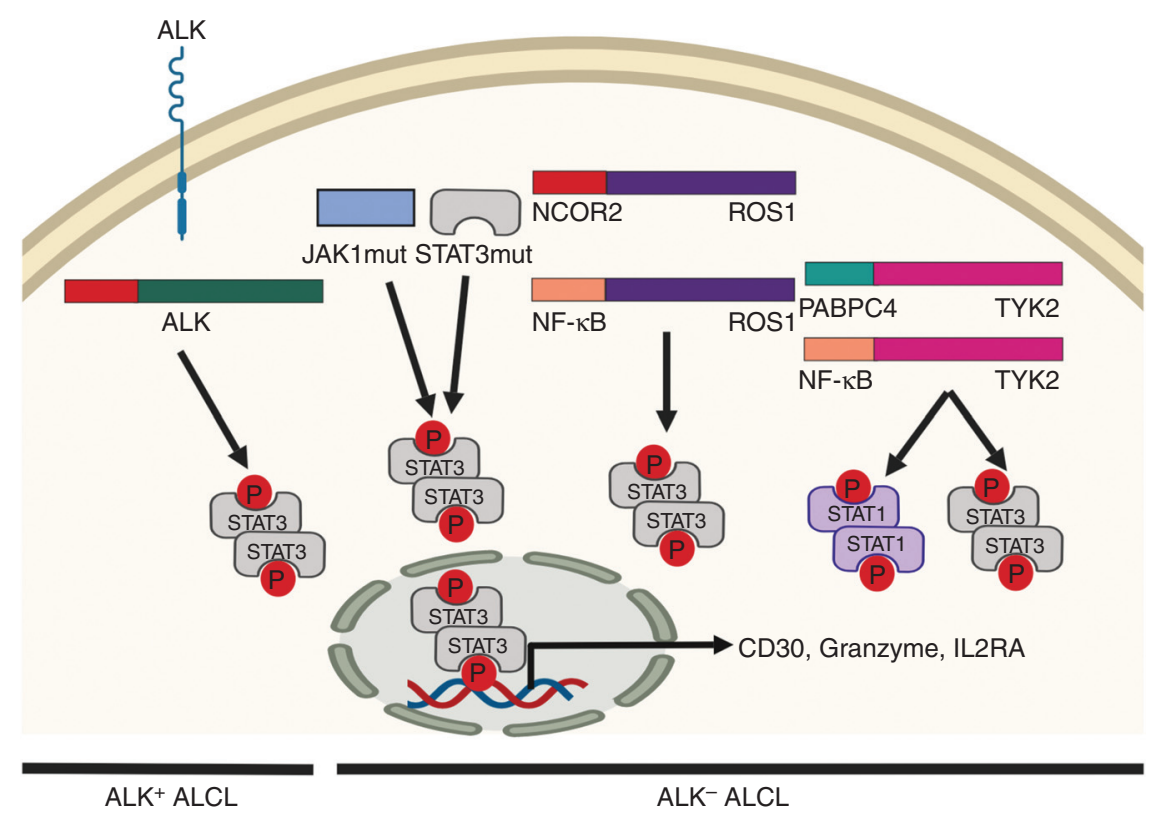

Figure 2. Recurrent mutations and kinase fusions in anaplastic large cell lymphoma (ALCL) converge to induce oncogenic STAT3 activation in $\mathrm{ALK}^{+}$and $\mathrm{ALK}^{-}$ALCL subtypes. (Figure was created from data adapted from Crescenzo et al. 2015.)

morphologic and phenotypic similarities between $\mathrm{ALK}^{+}$and $\mathrm{ALK}^{-}$ALCL (Fig. 2).

Finally, there is a novel provisional category, BIALCL, arising in association with prolonged exposure to breast implants, for which the factors leading to progression still remain to be determined (Miranda et al. 2014; Laurent et al. 2016).

\section{ADULT T-CELL LEUKEMIA/LYMPHOMA}

Adult T-cell leukemia/lymphoma (ATLL) is a mature T-cell lymphoma derived from the transformation of regulatory $\mathrm{T}$ cells and associated with the infection by the human T-cell lymphotropic virus type 1 (HTLV-1) (Bangham and Toulza 2011). In ATLL pathogenesis, viral products such as Tax and HBZ have important roles in oncogenic transformation (Giam and Semmes 2016). However, although the Tax gene, a nonstructural gene on the HTLV-1 genome, appears to play a critical role in transformation initiation, it is not critical to sustain tumor cell growth, and it is frequently no longer expressed in transformed cells. HBZ is one of the few genes consistently overexpressed in most ATLL cases (Bazarbachi et al. 2011). Interestingly, $<5 \%$ of HTLV1-infected individuals will eventually develop ATLL and only after a long latency (Giam and Semmes 2016); thus, other factors are required for transformation in a multistep process that might involve viral and epigenetic mechanisms in conjunction with acquired genomic alterations. ATLL is geographically restricted to those regions where HTLV-1 is endemic, including Japan, Central and South America, the Caribbean, and certain regions in western Africa. In this regard, the introduction of preventative approaches to reduce the spread of HTLV1 infection could have a significant impact on the incidence of ATLL.

Four different clinical presentations of ATLL have been described: acute, lymphomatous, chronic, and smoldering (Matutes 2007). The acute presentation is the most common and severe, being associated with the worst prognosis. Malignant cells have a classical nuclear morphology resembling a cloverleaf, and might 
express CD30. In most cases, ATLL cells express $\mathrm{CD} 3, \mathrm{CD} 4$, and CD25, and lack CD7, whereas in $10 \%-15 \%$ of cases, there is expression of CD 4 and CD8. The cell of origin of ATLL cells is hypothesized to be regulatory $\mathrm{T}$ cells based on the expression of FoxP3 in some tumor cells; however, the assignment remains controversial (Malcolm et al. 2016). ATLL cells are also characterized by high expression of CCR4 and CCR7 chemokine receptors, which are involved in ATLL cell migration and infiltration of lymphoid organs and skin (Ohshima 2015).

Analyses of large patient cohorts using next-generation sequencing approaches have delineated the molecular landscape of ATLL and identified recurrent somatic mutations and genetic aberrations affecting multiple elements of the TCR-NF- $\kappa \mathrm{B}$ signaling pathways (Kataoka et al. 2015). Thus, gain-of-function mutations and focal amplifications leading to constitutive activation of this pathway have been identified in proximal (CD28, PLCG1, $V A V 1, R H O A$ and $F Y N)$ and distal (PRKCB and CARD11) elements within the TCR-NF$\kappa \mathrm{B}$ pathway. Fusions involving CD28 such as CTLA4-CD28 and ICOS-CD28 are also recurrent. Mutations or deletions involving p16 and p53 tumor suppressors are common and generally associated with disease progression (Yamada and Kamihira 2005). Frequent mutations affecting CCR4 and CCR7 receptors, mostly involving truncation of the carboxy-terminal domains have been described. These mutations interfere with ligand-induced receptor internalization, leading to enhanced activation of downstream PI3K/AKT signaling (Kataoka et al. 2015). Finally, missense mutations affecting the NOTCH1 receptor have also been described in $30 \%$ of ATLL patients. The mutations affect the PEST domain of the NOTCH1 protein preventing the FBXW7-mediated degradation of NOTCH (Pancewicz et al. 2010). Interestingly, FBXW7 is also found mutated in $25 \%$ of ATLL (Yeh et al. 2016)

Several key transcription factors in lymphocyte activation and homeostasis are also recurrently mutated in ATLL. Thus, focal amplifications and frequent mutations in IRF4, a major downstream target of NF- $\mathrm{KB}$, confer gain-of- function activity to the mutated protein. GATA3, required for T-cell differentiation, is affected by nonsense and frameshift mutations distributed throughout the coding regions that result in dominant negative isoforms, whereas $I K Z F 2$ is frequently affected by intragenic deletions in more than one-third of ATLL patients, leading to abnormally spliced shorter forms that act as dominant negatives and have oncogenic activity in vivo.

Last, molecules associated with immune surveillance, such as $H L A-A / B, C D 58$, and $F A S$, are recurrently affected by loss-of-function mutations. Structural variations that truncate the PD-L1 $3^{\prime}$-untranslated region leading to its overexpression are also frequent (Kataoka et al. 2019). Interestingly, expression of PD-L1 in ATLL cells has been correlated with a poor prognosis (Miyoshi et al. 2016). This might be of relevance in the context of ATLL immunotherapy, considering recent reports describing rapid disease progression in ATLL patients receiving PD-1 inhibitor therapy (Ratner et al. 2018).

\section{NK/T-CELL LYMPHOMA}

Natural killer/T-cell lymphoma (NKTCL) is an aggressive type of non-Hodgkin lymphoma characterized by a clonal proliferation of NK T cells. It most commonly affects the upper respiratory and digestive tracts although sometimes it involves extranasal tissues such as the skin, gastrointestinal tract, soft tissues, and testis (de Mel et al. 2019b,a). NKTCL is most prevalent in Asians and the Native American populations of Mexico, Central America, and South America (Haverkos et al. 2016).

NKTCL is commonly associated with EBV viral infection (Suzuki 2014; Chaudhary et al. 2015; Komabayashi et al. 2017), although little is known about the genomic and transcriptomic profiles of EBV in NKTCL. Sequence variations of LMP1, a key latent protein with abilities to promote cell proliferation and inhibit cell apoptosis in NKTCL, have been demonstrated (Ito et al. 2014). It has been suggested that the role of LMP1 in NK and T cells is to increase the sensitivity of the infected cell to the growth-promoting effects of IL-2. 
Activation of the JAK/STAT pathway plays a prominent role in the pathogenesis of NKTCL, and up-regulation of IL2, IL10, and IFNGR1 are frequent events in NKTCL. JAK3-activating mutations promoting cytokine-independent STAT activation and enhancing NKTCL cell proliferation have also been described (Koo et al. 2012; Sim et al. 2017). Increased JAK/STAT signaling induces up-regulation of MYC and its interacting proteins (Huang et al. 2018); as well as phosphorylation of EZH2, a component of the Polycomb repressive complex 2 (PRC2), resulting in the up-regulation of genes involved in cell cycle regulation, DNA replication, invasiveness, and stemness (Yan et al. 2016).

In addition to the multiple modalities of JAK/STAT dysregulation in NKTCL, mutations in genes related to epigenetic modification are also common in NKTCL, including genes associated with histone methylation (KMT2D), histone acetylation (EP300), histone deubiquitination (ASXL3), and chromatin remodeling (ARID1A) (Choi et al. 2016).

\section{ENTEROPATHY-ASSOCIATED T-CELL LYMPHOMAS}

Enteropathy-associated T-cell lymphomas derive from the transformation of small intestinal intraepithelial lymphocytes (Chander et al. 2018). The most recent PTCL classification distinguishes between enteropathy-associated lymphoma closely linked to celiac disease (EATL, previously named EATL, type I) and monomorphic epitheliotropic intestinal T-cell lymphoma (MEITL, previously named EATL type II) (Swerdlow et al. 2016).

EATL is a rare entity usually associated to elderly individuals of Northern European descent (Delabie et al. 2011) and is a known complication of celiac disease, an autoimmune disorder characterized by gluten intolerance (Chander et al. 2018). Most EATLs were believed to arise from the neoplastic transformation of thymus-derived cytotoxic intraepithelial $\mathrm{TCR} \alpha \beta^{+} \mathrm{T}$ cells; however, recent reports have also suggested an origin of a subset of EATLs from intraepithelial TCR $\gamma \delta^{+} \mathrm{T}$ cells (Chander et al. 2018). Recurrent activating mutations in members of the JAK/STAT pathway, including JAK1 and STAT3, have been recently described in EATL (Roberti et al. 2016; Moffitt et al. 2017), which suggests deregulation of cytokine signaling to be an early event in lymphomagenesis.

MEITL is less common than EATL, shows no association with celiac disease, and occurs worldwide (Roberti et al. 2016). In the majority of the cases, MEITL neoplastic cells are derived from $\gamma \delta \mathrm{T}$ cells, although there are also exceptions (Chan et al. 2011; Swerdlow et al. 2016). Recurrent alterations in SETD2 are the hallmark of MEITL, being detected in $>90 \%$ of patients (Roberti et al. 2016). Additional mutations in other epigenetic regulators including CREBBP, ARID1, EP300, and EZH2 were also found at lower frequencies. Also recurrent were mutations affecting the JAK/STAT signaling pathway, including STAT5 and JAK3 (Kucuk et al. 2015; Nairismägi et al. 2016), the MAPK pathway (including BRAF, KRAS, and NRAS) and TP53 (Roberti et al. 2016).

\section{HEPATOSPLENIC T-CELL LYMPHOMA}

Hepatosplenic T-cell lymphoma (HSTCL) derives from nonactivated cytotoxic $\mathrm{T}$ cells. This rare entity is found in younger male patients, sometimes associated with chronic immunosuppression (Shi and Wang 2015). HSTCL primarily affects the liver, spleen, and frequently the bone marrow and is characterized by the expansion of malignant medium-sized $\mathrm{T}$ cells expressing cytotoxic markers (including $\mathrm{T} 1 \mathrm{Al}^{+}$ and granzyme $\mathrm{M}^{+}$) and killer immunoglobulin receptors (Kirs) (Yabe et al. 2018). The most common HSCTL type is derived from $\gamma / \delta$ T cells with a small percentage derived from $\alpha / \beta$ T cells (Shi and Wang 2015; Swerdlow et al. 2016), although both subtypes are otherwise clinically and genetically similar. The most frequent mutations identified in HSCTL affect chromatin-modifier genes such as the SETD2 tumor suppressor, INO80, and ARID1B, in addition to recurrent activating mutations affecting elements of the JAK/STAT pathway, predominantly STAT5B and less often STAT3, and PIK3CD (Nicolae et al. 2014; McKinney et al. 2017) 


\section{CUTANEOUS T-CELL LYMPHOMAS}

Cutaneous T-cell lymphomas (CTCLs) are characterized by the presence of skin-homing $\mathrm{CD}^{+}{ }^{+}$malignant $\mathrm{T}$ cells. Although current models place the origin of mature cutaneous $\mathrm{T}$-cell lymphomas from memory $\mathrm{T}$ cells in the periphery, there have also been reports of quiescent cancer precursor cells residing in bone marrow, which secondarily migrate to the skin producing clinically apparent cutaneous lymphoma lesions (Gniadecki et al. 2003; Hamrouni et al. 2019). Mycosis fungoides (MF) and Sézary syndrome (SS) are two major subtypes of CTCL, constituting $75 \%$ of the cases diagnosed as CTCL (Devata and Wilcox 2016). MF cases with limited skin involvement have a generally good prognosis; however, advanced skin involvement, presence of characteristic Sézary cells in peripheral blood and/or lymph node, and organ infiltration are associated with dismal outcomes.

Multiple genomic studies to define the mutational landscape of CTCL have demonstrated the existence of a marked genomic heterogeneity (Vaqué et al. 2014; Choi et al. 2015; da Silva Almeida et al. 2015; Ungewickell et al. 2015; Wang et al. 2015b). Common driver genetic lesions include mutations and copy number alterations affecting cell cycle regulators $(C D K N 1 B)$, chromatin-modifying genes (ARID1A, ARID5B, SMARCC1, DNMT3A, and TET2), DNA damage response genes, and immune evasion genes, as well as genes involved in T-cell signaling, migration, and differentiation (including a recurrent mutation in RHOA N117I of unknown significance). Frequent mutations and chromosomal deletions affecting TP53 have been identified in $>50 \%$ of the patients with CTCL (Chang et al. 2018). Genomic analysis of CTCL found recurrent gain-of-function mutations and amplifications affecting the JAK/STAT pathway, including JAK1, JAK3, STAT3, and STAT5B, resulting in the hyperactivation of this signaling pathway. In addition, the NF- $\kappa \mathrm{B}$ pathway is frequently targeted by somatic mutations in CTCL, including PLCG1, CARD11, TNFRSF1B, and recently $R L T P R$, a scaffolding protein that strongly upregulates the NF- $\kappa B$ signaling (Park et al. 2017).
The convergence of diverse mutations on this pathway, generally mutually exclusive, highlights the role of NF- $\kappa B$ signaling in CTCL lymphomagenesis and supports the potential therapeutic role for NF- $\mathrm{kB}$ inhibitors.

\section{NOVEL THERAPEUTIC APPROACHES FOR THE TREATMENT OF MATURE T-CELL LYMPHOMAS}

The current standard of care for mature T-cell lymphomas is based on traditional chemotherapy with an induction therapy using a combination of cyclophosphamide, doxorubicin, vincristine, and prednisone (CHOP) followed by stem cell transplant after first remission. Unfortunately, this therapeutic approach only achieves survival rates of $40 \%-50 \%$ and prognosis remains dismal for most of the PTCL subtypes (Lue et al. 2017). CHOP-based approaches are specifically ineffective in ATLL patients, who present low response rates with frequent relapses and short survival. In this specific group, antiretroviral treatment, combining zidovudine (AZT) and interferon alpha (IFN- $\alpha$ ), appears to be an option for first-line therapy (Bazarbachi et al. 2010).

The increased understanding of the biology of PTCL achieved during the past few years has supported an exponential rise in the development of novel targeted therapies in PTCL that are generally better tolerated and in multiple instances have achieved very significant responses (Table 2; Fig. 3). Most of these agents have been tested as second-line salvage therapies in relapsed/refractory PTCL and their efficacy has been mostly analyzed as single agents although a variety of clinical trials focused on novel drug combinations are also ongoing (Ma et al. 2018).

In general, PTCL exhibits a marked epigenetic dysregulation that supports the use of epigenetic modifiers including inhibitors of histone deacetylases (HDACs) and hypomethylating agents for the treatment of this disease.

Two widely used hypomethylating agents are decitabine (5-aza-2'-deoxycytidine) and 5-aza-cytidine, cytidine antimetabolite analogs that incorporate into DNA and inhibit DNA methyltransferases, resulting in hypomethyla- 
Pathogenesis of T-Cell Lymphomas

Table 2. Targeted therapies for PTCL: Small molecules, antibodies, and immune checkpoint inhibitors targeting molecular pathways

\begin{tabular}{|c|c|}
\hline Small molecules & Inhibitors \\
\hline Vorinostat & Histone deacetylases (HDACs) \\
\hline \multicolumn{2}{|l|}{ Romidepsin } \\
\hline \multicolumn{2}{|l|}{ Belinostat } \\
\hline \multicolumn{2}{|l|}{ Chidamide } \\
\hline Pralatrexate & Dihydrofolate reductase \\
\hline $\begin{array}{l}\text { Decitabine (5-aza-2' - } \\
\text { deoxycytidine) }\end{array}$ & DNA methyltransferases \\
\hline \multicolumn{2}{|l|}{ 5-aza-cytidine } \\
\hline Duvelisib & PI3 kinases \\
\hline \multicolumn{2}{|l|}{ Copanlisib } \\
\hline \multicolumn{2}{|l|}{ Tenalisib } \\
\hline Bortezomib & Blocks I $\kappa \mathrm{B}$ degradation and NF- $\kappa \mathrm{B}$ translocation by targeting $26 \mathrm{~S}$ proteasome \\
\hline Carfilzomib & 20S proteasome \\
\hline Ixazomib & Proteasome subunit beta type-5 (PSMB5) \\
\hline Everolimus & Targets FK506 binding protein-12 (FKBP-12) inhibiting mTORC1 \\
\hline Crizotinib & $\begin{array}{l}\text { Tyrosine kinase receptors: anaplastic lymphoma kinase (ALK), hepatocyte } \\
\text { growth factor receptor (HGFR) }\end{array}$ \\
\hline \multicolumn{2}{|l|}{ Antibodies } \\
\hline Mogamulizumab & CCR4 chemokine receptor \\
\hline Brentuximab vedotin & CD30 (TNFRSF8) \\
\hline Hu5F9-G4 & $\mathrm{CD} 47$ \\
\hline \multicolumn{2}{|l|}{ TTI-621 } \\
\hline \multicolumn{2}{|l|}{$\begin{array}{l}\text { Immune checkpoint } \\
\text { inhibitors }\end{array}$} \\
\hline Nivolumab & PD-L1 \\
\hline \multicolumn{2}{|l|}{ Durvalumab } \\
\hline Pembrolizumab & PD-1 \\
\hline
\end{tabular}

tion of DNA. Initial case reports demonstrated a positive outcome for AITL patients treated with 5-aza-cytidine (Cheminant et al. 2015; Saillard et al. 2016) and a clinical trial with relapsed PTCL patients resulted in 53\% overall response rate (ORR) and 75\% ORR when only AITL patients were analyzed (Saillard et al. 2016).

HDAC inhibitors constitute a class of smallmolecule inhibitors that activate gene expression by inhibiting HDAC activity. Although initially being considered as "epigenetic modifiers" with a predominant role in chromatin remodeling via histone acetylation, HDACis have been shown to exert wider more pleiotropic effects in tumor cells associated with acetylation of nonhistone proteins and regulation of DNA repair (O'Connor et al. 2014). Interestingly, HDACis have been particularly effective for the treatment of PTCL, and several have been approved by the U.S. Federal Drug Administration (FDA) including vorinostat (Duvic et al. 2007; Olsen et al. 2007), romidepsin (Piekarz et al. 2011; Coiffier et al. 2012, 2014; Maruyama et al. 2017b), and belinostat (Foss et al. 2015) with an additional HDACi, chidamide, being approved in China (Shi et al. 2017). Challenges remain to better define the patients that will respond to $\mathrm{HDACi}$, identify the mechanisms of resistance, and leverage the effectiveness of epigenetic modifiers alone and in combination. Indeed, a recent clinical trial combining oral 5azacytidine and romidepsin exhibited marked activity in patients with PTCL in a phase I clinical trial, with overall and complete response rates of $73 \%$ and $55 \%$, respectively, in patients with T-cell lymphoma (O’Connor et al. 2019).

Pralatrexate is an antifolate that works by inhibiting dihydrofolate reductase, leading to 
J.R. Cortés and T. Palomero

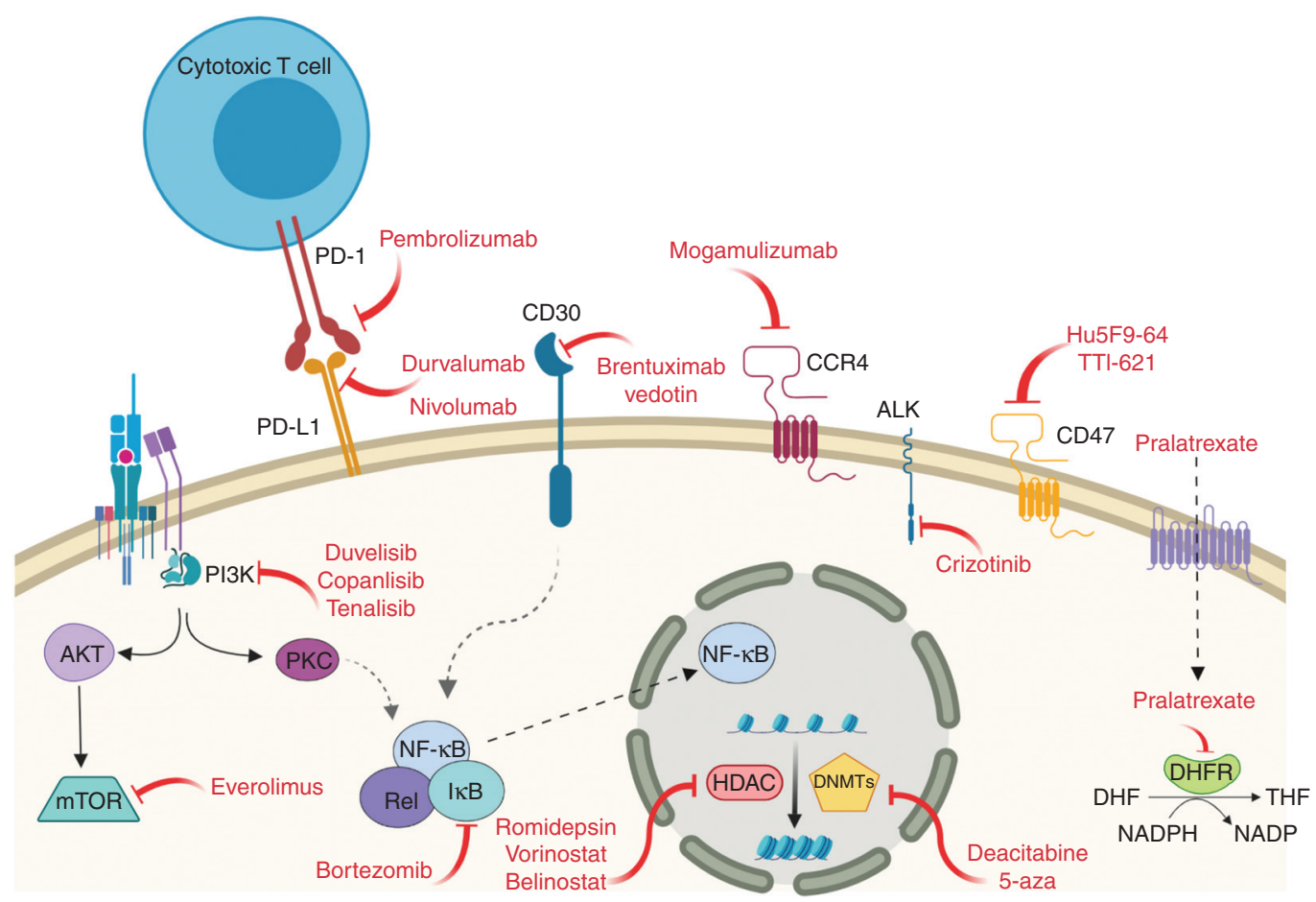

Figure 3. Relevant molecular pathways in PTCL amenable to therapeutic intervention using targeted therapies.

depletion of tetrahydrofolate with the subsequent inhibition of pyrimidines synthesis and tumor growth. Palatrexate was FDA-approved in 2009 after two independent clinical trials reported a $29 \%-45 \%$ response rate (O'Connor et al. 2011; Maruyama et al. 2017a).

The PI3 K/AKT signaling pathway is frequently activated in PTCL and pharmacologic inhibition of the PI3 K/AKT pathway has been extensively studied in preclinical models and has shown efficacy in T-cell malignancies (Cortés et al. 2018). Currently, several PI3 K inhibitors, including duvelisib (Horwitz et al. 2018), copanlisib (Dreyling et al. 2017), and tenalisib (Ito et al. 2019) with differential affinity for the different PI3 K subunits, are being tested in T-cell malignancies, where they are thought to mediate both cell autonomous effects on tumor cells and immune-mediated effects because of their activity on the tumor microenvironment (Horwitz et al. 2018).

Bortezomib is a proteasome inhibitor that blocks degradation of IкB and the proteolytic processing of p105, thereby inhibiting NF- $\mathrm{\kappa B}$ nuclear translocation (Wang et al. 2014). In mature lymphomas, the use of bortezomib led to an ORR of $67 \%$ in 15 patients with CTCL when used as single agent. In a phase II study in combination with CHOP in newly diagnosed PTCL cases, the drug combination achieved an $76 \%$ ORR (Kim et al. 2012). Newer proteasome inhibitors, including carfilzomib and ixazomib, are currently being tested in clinical trials for the treatment of relapsed PTCL in the context of drug combinations.

Everolimus, a derivative of rapamycin that inhibits the mTOR pathways, achieved an ORR of $44 \%$ as a single agent in relapsed or refractory lymphomas (Witzig et al. 2015), and a more recent phase II study with a combination of everolimus plus $\mathrm{CHOP}$ demonstrated an increased efficacy over CHOP alone (Kim et al. 2016).

Considering the prevalence of mutations affecting the JAK/STAT pathway in multiple subtypes of PTCL, treatment with small-molecule inhibitors targeting this pathway could have 
potential relevance for the treatment of PTCL. Recently, the JAK3 inhibitor tofacitinib has achieved hematologic responses in a phase I trial in TGL, whereas the dual SYK/JAK inhibitor cerdulatinib has also been studied in a phase II trial on relapsed PTCL achieving a 35\% overall response (Ng and Jacobsen 2019). Similarly, dasatinib, a multikinase inhibitor that targets members of the Src family of intracellular tyrosine kinases, has shown promising results for the treatment of AITL in a phase I trial, probably because of its inhibitory effect on the deregulated TCR signaling characteristic of this tumors (Nguyen et al. 2020)

Finally, crizotinib, a small-molecule inhibitor of the ALK tyrosine kinase, has been markedly successful in patients with ALK-positive ALCL, for whom treatment with crizotinib induced a 91\% response rate (Gambacorti Passerini et al. 2014). Crizotinib is currently being evaluated in additional clinical trials directed both at pediatric and adult populations. Additional ALK inhibitors are being considered as next-line therapy, anticipating the potential development of resistances to crizotinib (Sharma et al. 2018).

Development of immunotherapeutic approaches has become a major interest in the field of T-cell malignancies. Promising results have been obtained with the use of monoclonal antibodies, immune checkpoint inhibitors and CAR-T-cell therapies. Mogamulizumab, a humanized monoclonal antibody directed against the CCR4 chemokine receptor that is highly expressed in ATLL and CTCL subtypes (Ishida et al. 2003; Hristov et al. 2011), has demonstrated efficacy in patients with CCR4-positive ATLL, PTCL, and CTCL (Yamamoto et al. 2010; Ishida et al. 2012; Duvic et al. 2015; Kim et al. 2018). The results from the phase III clinical trial on CTCL patients demonstrated an overall response rate of $28 \%$ (Kim et al. 2018), leading to the approval of mogamulizumab by the FDA for the treatment of patients with ATLL and CTCL. Brentuximab vedotin is an antibodydrug conjugate that contains the microtubuledisrupting agent mono-methylauristatin $\mathrm{E}$ (MMAE) linked to an anti-CD30 monoclonal antibody. CD30 is highly expressed on activated
T cells as well as ALCL and at variable levels in other PTCL subtypes (Onaindia et al. 2016). Initial studies with anti-CD30 unconjugated antibodies have failed to show significant clinical responses (Ansell et al. 2007; Duvic et al. 2009); however, results from a phase II clinical trial using the MMAE-conjugated form showed impressive responses in ALCL (Pro et al. 2012) with a ORR of $86 \%$ and achievement of longterm remission. Significant improvement was also observed in CD30 ${ }^{+}$CTCL (Prince et al. 2017). However, clinical responses in PTCLNOS or AITL were modest (Horwitz et al. 2014; Lamarque et al. 2016) and likely due to the variability in CD30 expression (Bossard et al. 2014). A different approach to target CD30 has been demonstrated with the development of AFM13, a bispecific chimeric antibody containing an anti CD16A domain to recruit NK T cells linked to an anti CD30 domain, which achieved partial responses in the initial studies in refractory lymphoma (Rothe et al. 2015) and is currently being tested on patients with $\mathrm{CD}^{+} 0^{+}$lymphomas with cutaneous involvement.

Finally, different antibody molecules targeting CD47, a ubiquitous membrane protein that binds to SIRP $\alpha$ inhibiting macrophage phagocytosis and allowing escape from immune surveillance, are currently being studied in clinical trials. Inhibition of the CD47-SIRP $\alpha$ interaction results in activation of innate immunity and promotion of cancer cell destruction by macrophages. Hu5F9-G4, a humanized anti-CD47 blocking antibody (Liu et al. 2018), and TTI621 , a fusion protein containing the CD47 binding domain of human SIRP $\alpha$ and linked to the Fc region of IgG1 with enhanced antitumor activity, are two examples of CD47 targeting molecules under investigation. In an ongoing phase I study in CTCL patients, intratumoral injections of TTI-621 led to decreased tumor size (Folkes et al. 2018).

The past few years have witnessed an increased effort toward the implementation of immunotherapy approaches for the treatment of lymphoid malignancies. Blocking antibodies targeting CTLA-4, PD-L1, and PD-1 immune checkpoints have resulted in the development 
of highly effective antitumor responses in solid tumors; however, their indication for the treatment of mature $\mathrm{T}$-cell malignancies remains controversial. Although multiple trials are testing the effect of checkpoint inhibitors in PTCL, including nivolumab (Lesokhin et al. 2016), pembrolizumab (Kwong et al. 2017a,b), and durvalumab (Heyman and Yang 2018), recent reports have also described a role for $P D-1$ as a tumor suppressor in T-cell lymphomagenesis and demonstrated that $P d-1$ deletion in mouse models leads to highly aggressive lymphoma (Wartewig et al. 2017). Similarly, expansion of malignant clones and oncogenic activation of the TCR pathways have described associated to checkpoint inhibitor therapy in ATLL (Ratner et al. 2018). These results, together with the variable efficacy of checkpoint inhibitors in different PTCL subtypes, suggest that immunotherapy targeting of PD-1 needs to be carefully evaluated for disease stage, composition of the tumor microenvironment, $\mathrm{PD}-1$ genetic deletions, and TCR oncogenic alterations prior to treatment.

Modulating the immune system to eliminate tumor cells using CAR-T-cell-based cellular therapies has proven successful for the treatment of lymphoid malignancies, especially for patients with refractory or relapsed B-cell malignancies. However, treating T-cell malignancies has proven to be challenging endeavor because of the shared expression of many targetable antigens between normal and malignant $\mathrm{T}$ cells. This shared antigenicity can cause fratricide in CAR-transduced T cells, inhibiting their proliferation and viability, and in the clinic may also result in eradication of normal peripheral $\mathrm{T}$ cells leading to severe immunodeficiency and other serious side effects. Despite these caveats, significant progress has been made on the identification of targetable antigens and development of cell-based therapies for T-cell leukemia and lymphoma. CD30 represents an attractive and validated target for antibody-based therapies and its expression is generally restricted to lymphoma cells. CAR-T cells targeting CD30 have shown potent antilymphoma activity in preclinical studies in various tumor models (Hombach et al. 1999). In addition, recent success in targeting a constant region of the TCR beta chain (TRBC1) could prove relevant for the treatment of PTCL (Maciocia et al. 2017).

\section{CLOSING REMARKS}

In the past few years, multiple studies have led to an increased understanding of the pathogenesis and molecular classification of PTCL. Highthroughput studies have achieved a deeper understanding of the underlying disease biology and led to improved diagnostic accuracy based on the molecular classification of PTCL. The identification of novel therapeutic vulnerabilities has induced a significant shift in the clinical management of these diseases because of the introduction of targeted agents. The success of epigenetic drugs in PTCL, specifically of HDACi and hypomethylating agents, supports leveraging their use alone and in combination for the treatment of this disease. Many challenges and opportunities for improvement remain, including identification of biomarkers of response to targeted therapies, characterization of mechanisms of resistance, and development of successful combination therapies for the treatment of PTCL.

In addition, continuous progress toward the understanding of the mechanisms that drive $\mathrm{T}$-cell oncogenesis, generation of animal models, and patient-derived xenografts for the experimental therapeutics and implementation of immunotherapy approaches will be instrumental to improve survival for mature T-cell malignancies.

\section{ACKNOWLEDGMENTS}

The authors thank Dr. Adolfo Ferrando and Dr. Laura Belver for their insightful comments and their contribution to the editing of the manuscript. J.R.C. is a recipient of a Postdoctoral fellowship from the Lady Tata Research Foundation. T.P. is supported by National Institutes of Health (NIH) grants 1R01 CA197945-01 and U01 CAZ43073. J.R.C. and T.P. designed and wrote the manuscript.

Conflict-of-interest disclosure: T.P. is the recipient of a research grant from Kura Technologies. 


\section{REFERENCES}

Abate F, da Silva-Almeida AC, Zairis S, Robles-Valero J, Couronne L, Khiabanian H, Quinn SA, Kim MY, Laginestra MA, Kim C, et al. 2017. Activating mutations and translocations in the guanine exchange factor VAV1 in peripheral T-cell lymphomas. Proc Natl Acad Sci 114: 764-769. doi:10.1073/pnas.1608839114

Abdel-Wahab O, Mullally A, Hedvat C, Garcia-Manero G, Patel J, Wadleigh M, Malinge S, Yao J, Kilpivaara O, Bhat $\mathrm{R}$, et al. 2009. Genetic characterization of TET1, TET2, and TET3 alterations in myeloid malignancies. Blood 114: 144-147. doi:10.1182/blood-2009-03-210039

Ansell SM, Horwitz SM, Engert A, Khan KD, Lin T, Strair R, Keler T, Graziano R, Blanset D, Yellin M, et al. 2007. Phase I/II study of an anti-CD30 monoclonal antibody (MDX-060) in Hodgkin's lymphoma and anaplastic large-cell lymphoma. J Clin Oncol 25: 2764-2769. doi:10.1200/JCO.2006.07.8972

Bangham CR, Toulza F. 2011. Adult T cell leukemia/lymphoma: FoxP3 ${ }^{+}$cells and the cell-mediated immune response to HTLV-1. Adv Cancer Res 111: 163-182. doi:10 1016/B978-0-12-385524-4.00004-0

Bazarbachi A, Plumelle Y, Carlos Ramos J, Tortevoye P, Otrock Z, Taylor G, Gessain A, Harrington W, Panelatti G, Hermine O. 2010. Meta-analysis on the use of zidovudine and interferon-alfa in adult T-cell leukemia/lymphoma showing improved survival in the leukemic subtypes. J Clin Oncol 28: 4177-4183. doi:10.1200/JCO.2010.28 .0669

Bazarbachi A, Suarez F, Fields P, Hermine O. 2011. How I treat adult T-cell leukemia/lymphoma. Blood 118: 17361745. doi:10.1182/blood-2011-03-345702

Boi M, Rinaldi A, Kwee I, Bonetti P, Todarò M, Tabbò F, Piva R, Rancoita PM, Matolcsy A, Timar B, et al. 2013. $P R D M 1 / B L I M P 1$ is commonly inactivated in anaplastic large T-cell lymphoma. Blood 122: 2683-2693. doi:10 .1182/blood-2013-04-497933

Bossard C, Dobay MP, Parrens M, Lamant L, Missiaglia E, Haioun C, Martin A, Fabiani B, Delarue R, Tournilhac O, et al. 2014. Immunohistochemistry as a valuable tool to assess CD30 expression in peripheral T-cell lymphomas: High correlation with mRNA levels. Blood 124: $2983-$ 2986. doi:10.1182/blood-2014-07-584953

Busque L, Patel JP, Figueroa ME, Vasanthakumar A, Provost S, Hamilou Z, Mollica L, Li J, Viale A, Heguy A, et al 2012. Recurrent somatic TET2 mutations in normal elderly individuals with clonal hematopoiesis. Nat Genet 44: 1179-1181. doi:10.1038/ng.2413

Bustelo XR. 2000. Regulatory and signaling properties of the Vav family. Mol Cell Biol 20: 1461-1477. doi:10.1128/ MCB.20.5.1461-1477.2000

Cairns RA, Iqbal J, Lemonnier F, Kucuk C, de Leval L, Jais JP, Parrens M, Martin A, Xerri L, Brousset P, et al. 2012. $\mathrm{IDH} 2$ mutations are frequent in angioimmunoblastic Tcell lymphoma. Blood 119: 1901-1903. doi:10.1182/ blood-2011-11-391748

Chan JK, Chan AC, Cheuk W, Wan SK, Lee WK, Lui YH, Chan WK. 2011. Type II enteropathy-associated T-cell lymphoma: A distinct aggressive lymphoma with frequent $\gamma \delta$ T-cell receptor expression. Am J Surg Pathol 35: 1557-1569. doi:10.1097/PAS.0b013e318222dfcd
Chander U, Leeman-Neill RJ, Bhagat G. 2018. Pathogenesis of enteropathy-associated T cell lymphoma. Curr Hematol Malig Rep 13: 308-317. doi:10.1007/s11899-018-0459-5

Chang LW, Patrone CC, Yang W, Rabionet R, Gallardo F, Espinet B, Sharma MK, Girardi M, Tensen CP, Vermeer $\mathrm{M}$, et al. 2018. An integrated data resource for genomic analysis of cutaneous T-cell lymphoma. J Invest Dermatol 138: 2681-2683. doi:10.1016/j.jid.2018.06.176

Chaudhary RK, Bhatt VR, Vose JM. 2015. Management of extranodal natural killer/T-cell lymphoma, nasal type. Clin Lymphoma Myeloma Leuk 15: 245-252. doi:10 1016/j.clml.2014.12.014

Cheminant M, Bruneau J, Kosmider O, Lefrere F, Delarue R, Gaulard P, Radford I, Derrieux C, Hermine O, Lemonnier F. 2015. Efficacy of 5-azacytidine in a TET2 mutated angioimmunoblastic T cell lymphoma. Br J Haematol 168: 913-916. doi:10.1111/bjh.13170

Chiarle R, Simmons WJ, Cai H, Dhall G, Zamo A, Raz R, Karras JG, Levy DE, Inghirami G. 2005. Stat3 is required for ALK-mediated lymphomagenesis and provides a possible therapeutic target. Nat Med 11: 623-629. doi:10 $.1038 / \mathrm{nm} 1249$

Choi J, Goh G, Walradt T, Hong BS, Bunick CG, Chen K, Bjornson RD, Maman Y, Wang T, Tordoff J, et al. 2015. Genomic landscape of cutaneous T cell lymphoma. Nat Genet 47: 1011-1019. doi:10.1038/ng.3356

Choi S, Go JH, Kim EK, Lee H, Lee WM, Cho CS, Han K. 2016. Mutational analysis of extranodal NK/T-cell lymphoma using targeted sequencing with a comprehensive cancer panel. Genomics Inform 14: 78-84. doi:10.5808/GI 2016.14.3.78

Choudhari R, Minero VG, Menotti M, Pulito R, Brakebusch C, Compagno M, Voena C, Ambrogio C, Chiarle R. 2016. Redundant and nonredundant roles for Cdc42 and Rac1 in lymphomas developed in NPM-ALK transgenic mice. Blood 127: 1297-1306. doi:10.1182/blood-2015-11683052

Cimmino L, Abdel-Wahab O, Levine RL, Aifantis I. 2011. TET family proteins and their role in stem cell differentiation and transformation. Cell Stem Cell 9: 193-204. doi:10.1016/j.stem.2011.08.007

Coiffier B, Pro B, Prince HM, Foss F, Sokol L, Greenwood M, Caballero D, Borchmann P, Morschhauser F, Wilhelm M, et al. 2012. Results from a pivotal, open-label, phase II study of romidepsin in relapsed or refractory peripheral T-cell lymphoma after prior systemic therapy. J Clin Oncol 30: 631-636. doi:10.1200/JCO.2011.37.4223

Coiffier B, Pro B, Prince HM, Foss F, Sokol L, Greenwood M, Caballero D, Morschhauser F, Wilhelm M, Pinter-Brown L, et al. 2014. Romidepsin for the treatment of relapsed/ refractory peripheral T-cell lymphoma: pivotal study update demonstrates durable responses. J Hematol Oncol 7: 11. doi:10.1186/1756-8722-7-11

Cortés JR, Palomero T. 2016. The curious origins of angioimmunoblastic T-cell lymphoma. Curr Opin Hematol 23: 434-443. doi:10.1097/MOH.0000000000000261

Cortés JR, Ambesi-Impiombato A, Couronné L, Quinn SA, Kim CS, da Silva Almeida AC, West Z, Belver L, Martin MS, Scourzic L, et al. 2018. RHOA G17 V induces T follicular helper cell specification and promotes lymphomagenesis. Cancer Cell 33: 259-273.e7. doi:10.1016/j.ccell .2018.01.001 
J.R. Cortés and T. Palomero

Couronné L, Bastard C, Bernard OA. 2012. TET2 and DNMT3A mutations in human T-cell lymphoma. $N$ Engl J Med 366: 95-96. doi:10.1056/NEJMc1111708

Crescenzo R, Abate F, Lasorsa E, Tabbo F, Gaudiano M, Chiesa N, Di Giacomo F, Spaccarotella E, Barbarossa L, Ercole E, et al. 2015. Convergent mutations and kinase fusions lead to oncogenic STAT3 activation in anaplastic large cell lymphoma. Cancer Cell 27: 516-532. doi:10 1016/j.ccell.2015.03.006

da Silva Almeida AC, Abate F, Khiabanian H, MartinezEscala E, Guitart J, Tensen CP, Vermeer MH, Rabadan R, Ferrando A, Palomero T. 2015. The mutational landscape of cutaneous $T$ cell lymphoma and Sezary syndrome. Nat Genet 47: 1465-1470. doi:10.1038/ng.3442

de Leval L, Rickman DS, Thielen C, Reynies A, Huang YL, Delsol G, Lamant L, Leroy K, Brière J, Molina T, et al. 2007. The gene expression profile of nodal peripheral $\mathrm{T}$ cell lymphoma demonstrates a molecular link between angioimmunoblastic T-cell lymphoma (AITL) and follicular helper T (TFH) cells. Blood 109: 4952-4963. doi:10 .1182/blood-2006-10-055145

Delabie J, Holte H, Vose JM, Ullrich F, Jaffe ES, Savage KJ, Connors JM, Rimsza L, Harris NL, Müller-Hermelink K, et al. 2011. Enteropathy-associated T-cell lymphoma: Clinical and histological findings from the international peripheral T-cell lymphoma project. Blood 118: 148-155. doi:10.1182/blood-2011-02-335216

Delhommeau F, Dupont S, Della Valle V, James C, Trannoy S, Massé A, Kosmider O, Le Couedic JP, Robert F, Alberdi A, et al. 2009. Mutation in TET2 in myeloid cancers. N Engl J Med 360: 2289-2301. doi:10.1056/NEJMoa081 0069

de Mel S, Hue SS, Jeyasekharan AD, Chng WJ, Ng SB. 2019a Molecular pathogenic pathways in extranodal NK/T cell lymphoma. J Hematol Oncol 12: 33. doi:10.1186/s13045019-0716-7

de Mel S, Tan JZ, Jeyasekharan AD, Chng WJ, Ng SB. 2019b. Transcriptomic abnormalities in Epstein Barr virus associated T/NK lymphoproliferative disorders. Front Pediatr 6: 405. doi:10.3389/fped.2018.00405

Devata S, Wilcox RA. 2016. Cutaneous T-cell lymphoma: A review with a focus on targeted agents. Am J Clin Dermatol 17: 225-237. doi:10.1007/s40257-016-0177-5

Dreyling M, Morschhauser F, Bouabdallah K, Bron D, Cunningham D, Assouline SE, Verhoef G, Linton K, Thieblemont C, Vitolo U, et al. 2017. Phase II study of copanlisib, a PI3 K inhibitor, in relapsed or refractory, indolent or aggressive lymphoma. Ann Oncol 28: 2169-2178. doi:10 1093/annonc/mdx289

Duvic M, Talpur R, Ni X, Zhang C, Hazarika P, Kelly C, Chiao JH, Reilly JF, Ricker JL, Richon VM, et al. 2007. Phase 2 trial of oral vorinostat (suberoylanilide hydroxamic acid, SAHA) for refractory cutaneous T-cell lymphoma (CTCL). Blood 109: 31-39. doi:10.1182/ blood-2006-06-025999

Duvic M, Reddy SA, Pinter-Brown L, Korman NJ, Zic J, Kennedy DA, Lorenz J, Sievers EL, Kim YH. 2009. A phase II study of SGN-30 in cutaneous anaplastic large cell lymphoma and related lymphoproliferative disorders. Clin Cancer Res 15: 6217-6224. doi:10.1158/1078-0432 CCR-09-0162

Duvic M, Pinter-Brown LC, Foss FM, Sokol L, Jorgensen JL, Challagundla P, Dwyer KM, Zhang X, Kurman MR, Bal- lerini R, et al. 2015. Phase 1/2 study of mogamulizumab, a defucosylated anti-CCR4 antibody, in previously treated patients with cutaneous T-cell lymphoma. Blood 125: 1883-1889. doi:10.1182/blood-2014-09-600924

Federico M, Rudiger T, Bellei M, Nathwani BN, Luminari S, Coiffier B, Harris NL, Jaffe ES, Pileri SA, Savage KJ, et al. 2013. Clinicopathologic characteristics of angioimmunoblastic T-cell lymphoma: Analysis of the international peripheral T-cell lymphoma project. J Clin Oncol 31: 240-246. doi:10.1200/JCO.2011.37.3647

Ferreri AJ, Govi S, Pileri SA, Savage KJ. 2012. Anaplastic large cell lymphoma, ALK-positive. Crit Rev Oncol Hematol 83: 293-302. doi:10.1016/j.critrevonc.2012.02.005

Ferreri AJ, Govi S, Pileri SA, Savage KJ. 2013. Anaplastic large cell lymphoma, ALK-negative. Crit Rev Oncol Hematol 85: 206-215. doi:10.1016/j.critrevonc.2012.06.004

Folkes AS, Feng M, Zain JM, Abdulla F, Rosen ST, Querfeld C. 2018. Targeting CD47 as a cancer therapeutic strategy: The cutaneous T-cell lymphoma experience. Curr Opin Oncol 30: 332-337. doi:10.1097/CCO.000000000000 0468

Foss F, Advani R, Duvic M, Hymes KB, Intragumtornchai T, Lekhakula A, Shpilberg O, Lerner A, Belt RJ, Jacobsen ED, et al. 2015. A Phase II trial of Belinostat (PXD101) in patients with relapsed or refractory peripheral or cutaneous T-cell lymphoma. Br J Haematol 168: 811-819. doi:10.1111/bjh.13222

Fujisawa M, Sakata-Yanagimoto M, Nishizawa S, Komori D, Gershon P, Kiryu M, Tanzima S, Fukumoto K, Enami T, Muratani M, et al. 2018. Activation of RHOA-VAV1 signaling in angioimmunoblastic T-cell lymphoma. Leukemia 32: 694-702. doi:10.1038/leu.2017.273

Gambacorti Passerini C, Farina F, Stasia A, Redaelli S, Ceccon M, Mologni L, Messa C, Guerra L, Giudici G, Sala E, et al. 2014. Crizotinib in advanced, chemoresistant anaplastic lymphoma kinase-positive lymphoma patients. J Natl Cancer Inst 106: djt378. doi:10.1093/jnci/djt378

Gaulard P, de Leval L. 2014. The microenvironment in T-cell lymphomas: Emerging themes. Semin Cancer Biol 24: 49-60. doi:10.1016/j.semcancer.2013.11.004

Giam CZ, Semmes OJ. 2016. HTLV-1 infection and adult T-cell leukemia/lymphoma--A tale of two proteins: Tax and HBZ. Viruses 8: 161. doi:10.3390/v8060161

Gniadecki R, Lukowsky A, Rossen K, Madsen HO, Thomsen K, Wulf HC. 2003. Bone marrow precursor of extranodal T-cell lymphoma. Blood 102: 3797-3799. doi:10.1182/ blood-2003-03-0899

Hamrouni A, Fogh H, Zak Z, Ødum N, Gniadecki R. 2019. Clonotypic diversity of the T-cell receptor corroborates the immature precursor origin of cutaneous T-cell lymphoma. Clin Cancer Res 25: 3104-3114. doi:10.1158/ 1078-0432.CCR-18-4099

Haverkos BM, Pan Z, Gru AA, Freud AG, Rabinovitch R, Xu-Welliver M, Otto B, Barrionuevo C, Baiocchi RA, Rochford R, et al. 2016. Extranodal NK/T cell lymphoma, nasal type (ENKTL-NT): An update on epidemiology, clinical presentation, and natural history in North American and European cases. Curr Hematol Malig Rep 11: 514-527. doi:10.1007/s11899-016-0355-9

Heyman B, Yang Y. 2018. New developments in immunotherapy for lymphoma. Cancer Biol Med 15: 189-209. doi:10.20892/j.issn.2095-3941.2018.0037 
Hombach A, Heuser C, Sircar R, Tillmann T, Diehl V, Pohl C, Abken H. 1999. Characterization of a chimeric T-cell receptor with specificity for the Hodgkin's lymphomaassociated CD30 antigen. J Immunother 22: 473-480. doi:10.1097/00002371-199911000-00001

Horwitz SM, Advani RH, Bartlett NL, Jacobsen ED, Sharman JP, O'Connor OA, Siddiqi T, Kennedy DA, Oki Y. 2014. Objective responses in relapsed T-cell lymphomas with single-agent brentuximab vedotin. Blood 123: 30953100. doi:10.1182/blood-2013-12-542142

Horwitz SM, Koch R, Porcu P, Oki Y, Moskowitz A, Perez M, Myskowski P, Officer A, Jaffe JD, Morrow SN, et al. 2018. Activity of the PI3K- $\delta, \gamma$ inhibitor duvelisib in a phase 1 trial and preclinical models of T-cell lymphoma. Blood 131: 888-898. doi:10.1182/blood-2017-08-802470

Hristov AC, Vonderheid EC, Borowitz MJ. 2011. Simplified flow cytometric assessment in mycosis fungoides and Sézary syndrome. Am J Clin Pathol 136: 944-953. doi:10.1309/AJCP09OTJOYAVZZK

Huang L, Liu D, Wang N, Ling S, Tang Y, Wu J, Hao L, Luo $\mathrm{H}$, Hu X, Sheng L, et al. 2018. Integrated genomic analysis identifies deregulated JAK/STAT-MYC-biosynthesis axis in aggressive NK-cell leukemia. Cell Res 28: 172-186. doi:10.1038/cr.2017.146

Iqbal J, Wright G, Wang C, Rosenwald A, Gascoyne RD, Weisenburger DD, Greiner TC, Smith L, Guo S, Wilcox RA, et al. 2014. Gene expression signatures delineate biological and prognostic subgroups in peripheral T-cell lymphoma. Blood 123: 2915-2923. doi:10.1182/blood2013-11-536359

Ishida T, Utsunomiya A, Iida S, Inagaki H, Takatsuka Y, Kusumoto S, Takeuchi G, Shimizu S, Ito M, Komatsu $\mathrm{H}$, et al. 2003. Clinical significance of CCR4 expression in adult T-cell leukemia/lymphoma: Its close association with skin involvement and unfavorable outcome. Clin Cancer Res 9: 3625-3634.

Ishida T, Joh T, Uike N, Yamamoto K, Utsunomiya A, Yoshida S, Saburi Y, Miyamoto T, Takemoto S, Suzushima H, et al. 2012. Defucosylated anti-CCR4 monoclonal antibody (KW-0761) for relapsed adult T-cell leukemialymphoma: A multicenter phase II study. J Clin Oncol 30: 837-842. doi:10.1200/JCO.2011.37.3472

Ito S, D'Alessio AC, Taranova OV, Hong K, Sowers LC, Zhang Y. 2010. Role of Tet proteins in $5 \mathrm{mC}$ to $5 \mathrm{hmC}$ conversion, ES-cell self-renewal and inner cell mass specification. Nature 466: 1129-1133. doi:10.1038/na ture09303

Ito T, Kawazu H, Murata T, Iwata S, Arakawa S, Sato Y, Kuzushima K, Goshima F, Kimura H. 2014. Role of latent membrane protein 1 in chronic active Epstein-Barr virus infection-derived T/NK-cell proliferation. Cancer Med 3: 787-795. doi:10.1002/cam4.256

Ito Y, Makita S, Tobinai K. 2019. Development of new agents for peripheral T-cell lymphoma. Expert Opin Biol Ther 19: 197-209. doi:10.1080/14712598.2019.1572746

Kataoka K, Nagata Y, Kitanaka A, Shiraishi Y, Shimamura T, Yasunaga J, Totoki Y, Chiba K, Sato-Otsubo A, Nagae G, et al. 2015. Integrated molecular analysis of adult $\mathrm{T}$ cell leukemia/lymphoma. Nat Genet 47: 1304-1315. doi:10 1038/ng.3415

Kataoka K, Miyoshi H, Sakata S, Dobashi A, Couronné L, Kogure Y, Sato Y, Nishida K, Gion Y, Shiraishi Y, et al.
2019. Frequent structural variations involving programmed death ligands in Epstein-Barr virus-associated lymphomas. Leukemia 33: 1687-1699. doi:10.1038/ s41375-019-0380-5

Kim SJ, Yoon DH, Kang HJ, Kim JS, Park SK, Kim HJ, Lee J, Ryoo BY, Ko YH, Huh J, et al. 2012. Bortezomib in combination with $\mathrm{CHOP}$ as first-line treatment for patients with stage III/IV peripheral T-cell lymphomas: A multicentre, single-arm, phase 2 trial. Eur J Cancer 48: 3223 3231. doi:10.1016/j.ejca.2012.06.003

Kim SJ, Shin DY, Kim JS, Yoon DH, Lee WS, Lee H, Do YR, Kang HJ, Eom HS, Ko YH, et al. 2016. A phase II study of everolimus (RAD001), an mTOR inhibitor plus CHOP for newly diagnosed peripheral T-cell lymphomas. Ann Oncol 27: 712-718. doi:10.1093/annonc/mdv624

Kim YH, Bagot M, Pinter-Brown L, Rook AH, Porcu P, Horwitz SM, Whittaker S, Tokura Y, Vermeer M, Zinzani PL, et al. 2018. Mogamulizumab versus vorinostat in previously treated cutaneous T-cell lymphoma (MAVORIC): An international, open-label, randomised, controlled phase 3 trial. Lancet Oncol 19: 1192-1204. doi:10.1016/ S1470-2045(18)30379-6

Komabayashi Y, Kishibe K, Nagato T, Ueda S, Takahara M, Harabuchi Y. 2017. Circulating Epstein-Barr virus-encoded micro-RNAs as potential biomarkers for nasal natural killer/T-cell lymphoma. Hematol Oncol 35: 655-663. doi:10.1002/hon.2360

Koo GC, Tan SY, Tang T, Poon SL, Allen GE, Tan L, Chong SC, Ong WS, Tay K, Tao M, et al. 2012. Janus kinase 3activating mutations identified in natural killer/T-cell lymphoma. Cancer Discov 2: 591-597. doi:10.1158/ 2159-8290.CD-12-0028

Kucuk C, Hu X, Jiang B, Klinkebiel D, Geng H, Gong Q, Bouska A, Iqbal J, Gaulard P, McKeithan TW, et al. 2015. Global promoter methylation analysis reveals novel candidate tumor suppressor genes in natural killer cell lymphoma. Clin Cancer Res 21: 1699-1711. doi:10.1158/ 1078-0432.CCR-14-1216

Kwong YL, Chan TSY, Tan D, Kim SJ, Poon LM, Mow B, Khong PL, Loong F, Au-Yeung R, Iqbal J, et al. 2017a. PD1 blockade with pembrolizumab is highly effective in relapsed or refractory NK/T-cell lymphoma failing L-asparaginase. Blood 129: 2437-2442. doi:10.1182/blood2016-12-756841

Kwong YL, Lopes D, Khong PL. 2017b. Low-dose pembrolizumab induced remission in patients with refractory classical Hodgkin lymphoma. Br J Haematol 176: 131132. doi:10.1111/bjh.13920

Lamarque M, Bossard C, Contejean A, Brice P, Parrens M, Le Gouill S, Briere J, Bouabdallah R, Canioni D, Tilly H, et al. 2016. Brentuximab vedotin in refractory or relapsed peripheral T-cell lymphomas: The French named patient program experience in 56 patients. Haematologica 101: e103-e106. doi:10.3324/haematol.2015.135400

Laurent C, Delas A, Gaulard P, Haioun C, Moreau A, Xerri L, Traverse-Glehen A, Rousset T, Quintin-Roue I, Petrella T, et al. 2016. Breast implant-associated anaplastic large cell lymphoma: Two distinct clinicopathological variants with different outcomes. Ann Oncol 27: 306-314. doi:10 .1093/annonc/mdv575

Lemonnier F, Couronné L, Parrens M, Jaïs JP, Travert M, Lamant L, Tournillac O, Rousset T, Fabiani B, Cairns RA, 
J.R. Cortés and T. Palomero

et al. 2012. Recurrent TET2 mutations in peripheral T-cell lymphomas correlate with $\mathrm{T}_{\mathrm{FH}}$-like features and adverse clinical parameters. Blood 120: 1466-1469. doi:10.1182/ blood-2012-02-408542

Lesokhin AM, Ansell SM, Armand P, Scott EC, Halwani A, Gutierrez M, Millenson MM, Cohen AD, Schuster SJ, Lebovic D, et al. 2016. Nivolumab in patients with relapsed or refractory hematologic malignancy: Preliminary results of a Phase Ib Study. J Clin Oncol 34: 2698-2704. doi:10.1200/JCO.2015.65.9789

Liu B, Guo H, Xu J, Qin T, Guo Q, Gu N, Zhang D, Qian W, Dai J, Hou S, et al. 2018. Elimination of tumor by CD47/ PD-L1 dual-targeting fusion protein that engages innate and adaptive immune responses. MAbs 10: 315-324. doi:10.1080/19420862.2017.1409319

Lue JK, Kress A, Amengual JE. 2017. Therapeutic options for aggressive T-cell lymphomas. Curr Hematol Malig Rep 12: 269-281. doi:10.1007/s11899-017-0389-7

Lunning MA, Vose JM. 2017. Angioimmunoblastic T-cell lymphoma: The many-faced lymphoma. Blood 129: 1095-1102. doi:10.1182/blood-2016-09-692541

Ma H, Davarifar A, Amengual JE. 2018. The future of combination therapies for peripheral $\mathrm{T}$ cell lymphoma (PTCL). Curr Hematol Malig Rep 13: 13-24. doi:10 1007/s11899-018-0432-3

Maciocia PM, Wawrzyniecka PA, Philip B, Ricciardelli I, Akarca AU, Onuoha SC, Legut M, Cole DK, Sewell AK, Gritti G, et al. 2017. Targeting the T cell receptor $\beta$-chain constant region for immunotherapy of $\mathrm{T}$ cell malignancies. Nat Med 23: 1416-1423. doi:10.1038/nm.4444

Malcolm TI, Villarese P, Fairbairn CJ, Lamant L, Trinquand A, Hook CE, Burke GA, Brugières L, Hughes K, Payet D, et al. 2016. Anaplastic large cell lymphoma arises in thymocytes and requires transient TCR expression for thymic egress. Nat Commun 7: 10087. doi:10.1038/ ncomms 10087

Maruyama D, Nagai H, Maeda Y, Nakane T, Shimoyama T, Nakazato T, Sakai R, Ishikawa T, Izutsu K, Ueda R, et al. 2017a. Phase I/II study of pralatrexate in Japanese patients with relapsed or refractory peripheral T-cell lymphoma. Cancer Sci 108: 2061-2068. doi:10.1111/cas. 13340

Maruyama D, Tobinai K, Ogura M, Uchida T, Hatake K, Taniwaki M, Ando K, Tsukasaki K, Ishida T, Kobayashi $\mathrm{N}$, et al. 2017b. Romidepsin in Japanese patients with relapsed or refractory peripheral T-cell lymphoma: A phase I/II and pharmacokinetics study. Int J Hematol 106: 655-665. doi:10.1007/s12185-017-2286-1

Matutes E. 2007. Adult T-cell leukaemia/lymphoma. J Clin Pathol 60: 1373-1377. doi:10.1136/jcp.2007.052456

McKinney M, Moffitt AB, Gaulard P, Travert M, De Leval L, Nicolae A, Raffeld M, Jaffe ES, Pittaluga S, Xi L, et al. 2017. The genetic basis of hepatosplenic T-cell lymphoma. Cancer Discov 7: 369-379. doi:10.1158/2159-8290.CD16-0330

Menotti M, Ambrogio C, Cheong TC, Pighi C, Mota I, Cassel SH, Compagno M, Wang Q, Dall'Olio R, Minero VG, et al. 2019. Wiskott-Aldrich syndrome protein (WASP) is a tumor suppressor in T cell lymphoma. Nat Med 25: 130-140. doi:10.1038/s41591-018-0262-9

Miranda RN, Aladily TN, Prince HM, Kanagal-Shamanna R, de Jong D, Fayad LE, Amin MB, Haideri N, Bhagat G Brooks GS, et al. 2014. Breast implant-associated anaplas- tic large-cell lymphoma: Long-term follow-up of $60 \mathrm{pa}$ tients. JClin Oncol 32: 114-120. doi:10.1200/JCO.2013.52 .7911

Miyoshi H, Kiyasu J, Kato T, Yoshida N, Shimono J, Yokoyama S, Taniguchi H, Sasaki Y, Kurita D, Kawamoto $\mathrm{K}$, et al. 2016. PD-L1 expression on neoplastic or stromal cells is respectively a poor or good prognostic factor for adult T-cell leukemia/lymphoma. Blood 128: 1374-1381. doi:10.1182/blood-2016-02-698936

Moffitt AB, Ondrejka SL, McKinney M, Rempel RE, Goodlad JR, Teh CH, Leppa S, Mannisto S, Kovanen PE, Tse E, et al. 2017. Enteropathy-associated T cell lymphoma subtypes are characterized by loss of function of SETD2.J Exp Med 214: 1371-1386. doi:10.1084/jem.20160894

Moran-Crusio K, Reavie L, Shih A, Abdel-Wahab O, Ndiaye-Lobry D, Lobry C, Figueroa ME, Vasanthakumar A, Patel J, Zhao X, et al. 2011. Tet2 loss leads to increased hematopoietic stem cell self-renewal and myeloid transformation. Cancer Cell 20: 11-24. doi:10.1016/j.ccr.2011 .06 .001

Nagao R, Kikuti YY, Carreras J, Kikuchi T, Miyaoka M, Matsushita H, Kojima M, Ando K, Sakata-Yanagimoto M, Chiba S, et al. 2016. Clinicopathologic analysis of angioimmunoblastic T-cell lymphoma with or without RHOA G17 V mutation using formalin-fixed paraffinembedded sections. Am J Surg Pathol 40: 1041-1050. doi:10.1097/PAS.0000000000000651

Nairismägi ML, Tan J, Lim JQ, Nagarajan S, Ng CC, Rajasegaran V, Huang D, Lim WK, Laurensia Y, Wijaya GC, et al. 2016. JAK-STAT and G-protein-coupled receptor signaling pathways are frequently altered in epitheliotropic intestinal T-cell lymphoma. Leukemia 30: 13111319. doi:10.1038/leu.2016.13

Ng SY, Jacobsen ED. 2019. Peripheral T-cell lymphoma: Moving toward targeted therapies. Hematol Oncol Clin North Am 33: 657-668. doi:10.1016/j.hoc.2019.04.002

Ng SY, Brown L, Stevenson K, deSouza T, Aster JC, Louissaint A, Weinstock DM. 2018. RhoA G17 V is sufficient to induce autoimmunity and promotes $\mathrm{T}$ cell lymphomagenesis in mice. Blood 132: 935-947.

Nguyen TB, Sakata-Yanagimoto M, Fujisawa M, Nuhat ST, Miyoshi H, Nannya Y, Hashimoto K, Fukumoto K, Bernard OA, Kiyoki Y, et al. 2020. Dasatinib is an effective treatment for angioimmunoblastic T-cell lymphoma. Cancer Res doi: 10.1158/0008-5472.CAN-19-2787.

Nicolae A, Xi L, Pittaluga S, Abdullaev Z, Pack SD, Chen J, Waldmann TA, Jaffe ES, Raffeld M. 2014. Frequent STAT5B mutations in $\gamma \delta$ hepatosplenic T-cell lymphomas. Leukemia 28: 2244-2248. doi:10.1038/leu.2014.200

O'Connor OA, Pro B, Pinter-Brown L, Bartlett N, Popplewell L, Coiffier B, Lechowicz MJ, Savage KJ, Shustov AR, Gisselbrecht C, et al. 2011. Pralatrexate in patients with relapsed or refractory peripheral T-cell lymphoma: Results from the pivotal PROPEL study. J Clin Oncol 29: 11821189. doi:10.1200/JCO.2010.29.9024

O'Connor OA, Bhagat G, Ganapathi K, Pedersen MB, D'Amore F, Radeski D, Bates SE. 2014. Changing the paradigms of treatment in peripheral T-cell lymphoma: From biology to clinical practice. Clin Cancer Res 20: 5240-5254. doi:10.1158/1078-0432.CCR-14-2020

O'Connor OA, Falchi L, Lue JK, Marchi E, Kinahan C, Sawas A, Deng C, Montanari F, Amengual JE, Kim HA, et al. 
2019. Oral 5-azacytidine and romidepsin exhibit marked activity in patients with PTCL: A multicenter phase 1 study. Blood 134: 1395-1405. doi:10.1182/blood .2019001285

Ohshima K. 2015. Molecular pathology of adult T-cell leukemia/lymphoma. Oncology 89: 7-15. doi:10.1159/ 000431058

Olsen EA, Kim YH, Kuzel TM, Pacheco TR, Foss FM, Parker S, Frankel SR, Chen C, Ricker JL, Arduino JM, et al. 2007. Phase IIb multicenter trial of vorinostat in patients with persistent, progressive, or treatment refractory cutaneous T-cell lymphoma. J Clin Oncol 25: 3109-3115. doi:10 $1200 / J C O .2006 .10 .2434$

Onaindia A, Martínez N, Montes-Moreno S, Almaraz C, Rodríguez-Pinilla SM, Cereceda L, Revert JB, Ortega C, Tardio A, González L, et al. 2016. CD30 expression by B and $\mathrm{T}$ cells: $\mathrm{A}$ frequent finding in angioimmunoblastic T-cell lymphoma and peripheral T-cell lymphoma-not otherwise specified. Am J Surg Pathol 40: 378-385. doi:10.1097/PAS.0000000000000571

Ondrejka SL, Grzywacz B, Bodo J, Makishima H, Polprasert C, Said JW, Przychodzen B, Maciejewski JP, Hsi ED. 2016. Angioimmunoblastic T-cell lymphomas with the RHOA p.Gly17Val mutation have classic clinical and pathologic features. Am J Surg Pathol 40: 335-341. doi:10.1097/PAS .0000000000000555

Palomero T, Couronné L, Khiabanian H, Kim MY, AmbesiImpiombato A, Perez-Garcia A, Carpenter Z, Abate F, Allegretta M, Haydu JE, et al. 2014. Recurrent mutations in epigenetic regulators, $R H O A$ and FYN kinase in peripheral T cell lymphomas. Nat Genet 46: 166-170. doi:10 $.1038 /$ ng.2873

Pancewicz J, Taylor JM, Datta A, Baydoun HH, Waldmann TA, Hermine O, Nicot C. 2010. Notch signaling contributes to proliferation and tumor formation of human T-cell leukemia virus type 1-associated adult T-cell leukemia. Proc Natl Acad Sci 107: 16619-16624. doi:10 $.1073 /$ pnas. 1010722107

Park J, Yang J, Wenzel AT, Ramachandran A, Lee WJ, Daniels JC, Kim J, Martinez-Escala E, Amankulor N, Pro B, et al. 2017. Genomic analysis of 220 CTCLs identifies a novel recurrent gain-of-function alteration in RLTPR ( $\mathrm{p}$. Q575E). Blood 130: 1430-1440. doi:10.1182/blood-201702-768234

Parrilla Castellar ER, Jaffe ES, Said JW, Swerdlow SH, Ketterling RP, Knudson RA, Sidhu JS, Hsi ED, Karikehalli S, Jiang L, et al. 2014. ALK-negative anaplastic large cell lymphoma is a genetically heterogeneous disease with widely disparate clinical outcomes. Blood 124: 14731480. doi:10.1182/blood-2014-04-571091

Piekarz RL, Frye R, Prince HM, Kirschbaum MH, Zain J, Allen SL, Jaffe ES, Ling A, Turner M, Peer CJ, et al. 2011. Phase 2 trial of romidepsin in patients with peripheral Tcell lymphoma. Blood 117: 5827-5834. doi:10.1182/ blood-2010-10-312603

Prince HM, Kim YH, Horwitz SM, Dummer R, Scarisbrick J, Quaglino P, Zinzani PL, Wolter P, Sanches JA, Ortiz-Romero PL, et al. 2017. Brentuximab vedotin or physician's choice in CD30-positive cutaneous T-cell lymphoma (ALCANZA): An international, open-label, randomised, phase 3, multicentre trial. Lancet 390: 555-566. doi:10 .1016/S0140-6736(17)31266-7
Pro B, Advani R, Brice P, Bartlett NL, Rosenblatt JD, Illidge T, Matous J, Ramchandren R, Fanale M, Connors JM, et al. 2012. Brentuximab vedotin (SGN-35) in patients with relapsed or refractory systemic anaplastic large-cell lymphoma: Results of a phase II study. J Clin Oncol 30: 2190-2196. doi:10.1200/JCO.2011.38.0402

Ratner L, Waldmann TA, Janakiram M, Brammer JE. 2018. Rapid progression of adult T-cell leukemia-lymphoma after PD-1 inhibitor therapy. N Engl J Med 378: $1947-$ 1948. doi:10.1056/NEJMc1803181

Roberti A, Dobay MP, Bisig B, Vallois D, Boéchat C, Lanitis E, Bouchindhomme B, Parrens MC, Bossard C, Quintanilla-Martinez L, et al. 2016. Type II enteropathy-associated $\mathrm{T}$-cell lymphoma features a unique genomic profile with highly recurrent SETD2 alterations. Nat Commun 7: 12602. doi: $10.1038 /$ ncomms 12602

Rohr J, Guo S, Huo J, Bouska A, Lachel C, Li Y, Simone PD, Zhang W, Gong Q, Wang C, et al. 2015. Recurrent activating mutations of $\mathrm{CD} 28$ in peripheral T-cell lymphomas. Leukemia 30: 1062-1070. doi:10.1038/leu.2015.357

Rothe A, Sasse S, Topp MS, Eichenauer DA, Hummel H, Reiners KS, Dietlein M, Kuhnert G, Kessler J, Buerkle C, et al. 2015. A phase 1 study of the bispecific anti-CD30/ CD16A antibody construct AFM13 in patients with relapsed or refractory Hodgkin lymphoma. Blood 125: 4024-4031. doi:10.1182/blood-2014-12-614636

Saillard C, El Cheikh J, Granata A, Coso D, Schiano JM, Bouabdallah R, Blaise D, Charrier N, Broussais F. 2016. Histone deacetylase inhibitor abexinostat (S78454/PCI24781) as a successful approach in a case of refractory peripheral angio-immunoblastic T-cell lymphoma, as a bridge to reduced intensity conditioning haplo-identical allogenic stem cell transplant. Leuk Lymphoma 57: 714716. doi:10.3109/10428194.2015.1061190

Sakata-Yanagimoto M, Enami T, Yoshida K, Shiraishi Y, Ishii R, Miyake Y, Muto H, Tsuyama N, Sato-Otsubo A, Okuno Y, et al. 2014. Somatic RHOA mutation in angioimmunoblastic $\mathrm{T}$ cell lymphoma. Nat Genet 46: 171-175. doi:10.1038/ng.2872

Savage KJ. 2008. Peripheral T-cell lymphomas: An historical perspective. Hematology Am Soc Hematol Educ Program 271. doi:10.1182/asheducation-2008.1.271

Scourzic L, Couronné L, Pedersen MT, Della Valle V, Diop M, Mylonas E, Calvo J, Mouly E, Lopez CK, Martin N, et al. 2016. DNMT3A ${ }^{R 82 H}$ mutant and Tet2 inactivation cooperate in the deregulation of DNA methylation control to induce lymphoid malignancies in mice. Leukemia 30: 1388-1398. doi:10.1038/leu.2016.29

Sharma GG, Mota I, Mologni L, Patrucco E, GambacortiPasserini C, Chiarle R. 2018. Tumor resistance against ALK targeted therapy-Where it comes from and where it goes. Cancers (Basel) 10: 62 .

Shi Y, Wang E. 2015. Hepatosplenic T-cell lymphoma: A clinicopathologic review with an emphasis on diagnostic differentiation from other T-cell/natural killer-cell neoplasms. Arch Pathol Lab Med 139: 1173-1180. doi:10 .5858/arpa.2014-0079-RS

Shi Y, Jia B, Xu W, Li W, Liu T, Liu P, Zhao W, Zhang H, Sun $\mathrm{X}$, Yang H, et al. 2017. Chidamide in relapsed or refractory peripheral $\mathrm{T}$ cell lymphoma: A multicenter realworld study in China. J Hematol Oncol 10: 69. doi:10 $.1186 / \mathrm{s} 13045-017-0439-6$ 
Shustov A, Soma L. 2019. Anaplastic large cell lymphoma: Contemporary concepts and optimal management. Cancer Treat Res 176: 127-144. doi:10.1007/978-3-31999716-2_6

Sim SH, Kim S, Kim TM, Jeon YK, Nam SJ, Ahn YO, Keam B, Park HH, Kim DW, Kim CW, et al. 2017. Novel JAK3activating mutations in extranodal NK/T-cell lymphoma, nasal type. Am J Pathol 187: 980-986. doi:10.1016/j .ajpath.2017.01.004

Steensma DP. 2018. Clinical consequences of clonal hematopoiesis of indeterminate potential. Blood Adv 2: 34043410. doi:10.1182/bloodadvances.2018020222

Steensma DP, Ebert BL. 2020. Clonal hematopoiesis as a model for premalignant changes during aging. Exp Hematol 83: 48-56. doi:10.1016/j.exphem.2019.12.001

Suzuki R. 2014. Pathogenesis and treatment of extranodal natural killer/T-cell lymphoma. Semin Hematol 51: 42 51. doi:10.1053/j.seminhematol.2013.11.007

Swerdlow SH, Campo E, Pileri SA, Harris NL, Stein H, Siebert R, Advani R, Ghielmini M, Salles GA, Zelenetz AD et al. 2016. The 2016 revision of the World Health Organization classification of lymphoid neoplasms. Blood 127: 2375-2390. doi:10.1182/blood-2016-01-643569

Tahiliani M, Koh KP, Shen Y, Pastor WA, Bandukwala H, Brudno Y, Agarwal S, Iyer LM, Liu DR, Aravind L, et al. 2009. Conversion of 5-methylcytosine to 5-hydroxymethylcytosine in mammalian DNA by MLL partner TET1. Science 324: 930-935. doi:10.1126/sci ence. 1170116

Ungewickell A, Bhaduri A, Rios E, Reuter J, Lee CS, Mah A, Zehnder A, Ohgami R, Kulkarni S, Armstrong R, et al. 2015. Genomic analysis of mycosis fungoides and Sézary syndrome identifies recurrent alterations in TNFR2. Nat Genet 47: 1056-1060. doi:10.1038/ng.3370

Vallois D, Dobay MP, Morin RD, Lemonnier F, Missiaglia E, Juilland M, Iwaszkiewicz J, Fataccioli V, Bisig B, Roberti A, et al. 2016. Activating mutations in genes related to TCR signaling in angioimmunoblastic and other follicular helper T-cell-derived lymphomas. Blood 128: 14901502. doi:10.1182/blood-2016-02-698977

Vaqué JP, Gómez-López G, Monsálvez V, Varela I, Martínez N, Pérez C, Domínguez O, Graña O, Rodríguez-Peralto JL, Rodríguez-Pinilla SM, et al. 2014. PLCG1 mutations in cutaneous T-cell lymphomas. Blood 123: 2034-2043. doi:10.1182/blood-2013-05-504308

Wang H, Guan F, Chen D, Dou QP, Yang H. 2014. An analysis of the safety profile of proteasome inhibitors for treating various cancers. Expert Opin Drug Saf 13: 1043-1054. doi:10.1517/14740338.2014.939953

Wang C, McKeithan TW, Gong Q, Zhang W, Bouska A, Rosenwald A, Gascoyne RD, Wu X, Wang J, Muhammad $\mathrm{Z}$, et al. 2015a. IDH2 $2^{R 172}$ mutations define a unique subgroup of patients with angioimmunoblastic T-cell lymphoma. Blood 126: 1741-1752. doi:10.1182/blood-201505-644591

Wang L, Ni X, Covington KR, Yang BY, Shiu J, Zhang X, Xi L, Meng Q, Langridge T, Drummond J, et al. 2015b. Genomic profiling of Sézary syndrome identifies alterations of key T cell signaling and differentiation genes. Nat Genet 47: 1426-1434. doi:10.1038/ng.3444

Wartewig T, Kurgyis Z, Keppler S, Pechloff K, Hameister E, Öllinger R, Maresch R, Buch T, Steiger K, Winter C, et al.
2017. PD-1 is a haploinsufficient suppressor of T cell lymphomagenesis. Nature 552: 121-125. doi:10.1038/na ture24649

Watatani Y, Sato Y, Miyoshi H, Sakamoto K, Nishida K, Gion Y, Nagata Y, Shiraishi Y, Chiba K, Tanaka H, et al. 2019. Molecular heterogeneity in peripheral T-cell lymphoma, not otherwise specified revealed by comprehensive genetic profiling. Leukemia 33: 2867-2883. doi:10.1038/ s41375-019-0473-1

Weisenburger DD, Savage KJ, Harris NL, Gascoyne RD, Jaffe ES, MacLennan KA, Rüdiger T, Pileri S, Nakamura S, Nathwani B, et al. 2011. Peripheral T-cell lymphoma, not otherwise specified: A report of 340 cases from the International Peripheral T-cell Lymphoma Project. Blood 117: 3402-3408. doi:10.1182/blood-2010-09-310342

Witzig TE, Reeder C, Han JJ, LaPlant B, Stenson M, Tun HW, Macon W, Ansell SM, Habermann TM, Inwards DJ, et al. 2015. The mTORC1 inhibitor everolimus has antitumor activity in vitro and produces tumor responses in patients with relapsed T-cell lymphoma. Blood 126: 328335. doi:10.1182/blood-2015-02-629543

Yabe M, Miranda RN, Medeiros LJ. 2018. Hepatosplenic Tcell lymphoma: A review of clinicopathologic features, pathogenesis, and prognostic factors. Hum Pathol 74: 5-16. doi:10.1016/j.humpath.2018.01.005

Yamada Y, Kamihira S. 2005. Inactivation of tumor suppressor genes and the progression of adult T-cell leukemialymphoma. Leuk Lymphoma 46: 1553-1559. doi:10 $.1080 / 10428190500244217$

Yamamoto K, Utsunomiya A, Tobinai K, Tsukasaki K, Uike N, Uozumi K, Yamaguchi K, Yamada Y, Hanada S, Tamura K, et al. 2010. Phase I study of KW-0761, a defucosylated humanized anti-CCR4 antibody, in relapsed patients with adult T-cell leukemia-lymphoma and peripheral T-cell lymphoma. J Clin Oncol 28: 1591-1598. doi:10.1200/JCO.2009.25.3575

Yan J, Li B, Lin B, Lee PT, Chung TH, Tan J, Bi C, Lee XT, Selvarajan V, Ng SB, et al. 2016. EZH2 phosphorylation by JAK3 mediates a switch to noncanonical function in natural killer/T-cell lymphoma. Blood 128: 948-958. doi:10.1182/blood-2016-01-690701

Yao WQ, Wu F, Zhang W, Chuang SS, Thompson JS, Chen Z, Zhang SW, Clipson A, Wang M, Liu H, et al. 2020. Angioimmunoblastic T-cell lymphoma contains multiple clonal T-cell populations derived from a common TET2 mutant progenitor cell. J Pathol 250: 346-357. doi:10 $.1002 /$ path. 5376

Yeh CH, Bellon M, Pancewicz-Wojtkiewicz J, Nicot C. 2016. Oncogenic mutations in the FBXW7 gene of adult T-cell leukemia patients. Proc Natl Acad Sci 113: 6731-6736. doi:10.1073/pnas.1601537113

Yoo HY, Sung MK, Lee SH, Kim S, Lee H, Park S, Kim SC, Lee B, Rho K, Lee JE, et al. 2014. A recurrent inactivating mutation in RHOA GTPase in angioimmunoblastic T cell lymphoma. Nat Genet 46: 371-375. doi:10.1038/ng.2916

Zhou Y, Attygalle AD, Chuang SS, Diss T, Ye H, Liu H, Hamoudi RA, Munson P, Bacon CM, Dogan A, et al. 2007. Angioimmunoblastic T-cell lymphoma: Histological progression associates with $E B V$ and $H H V 6 B$ viral load. $\mathrm{Br} J$ Haematol 138: 44-53. doi:10.1111/j.13652141.2007.06620.x 


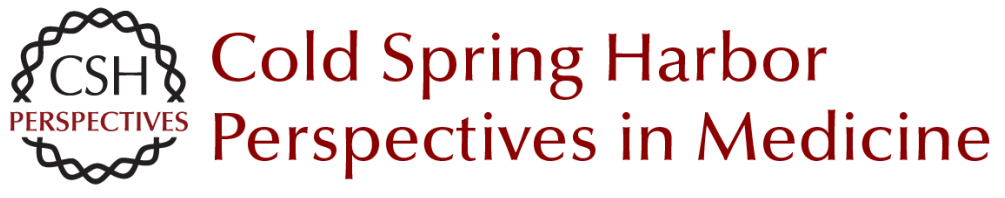

\section{Biology and Molecular Pathogenesis of Mature T-Cell Lymphomas}

José R. Cortés and Teresa Palomero

Cold Spring Harb Perspect Med 2021; doi: 10.1101/cshperspect.a035402 originally published online June 8, 2020

\section{Subject Collection Leukemia and Lymphoma: Molecular and Therapeutic Insights}

Oncogenic Mechanisms and Therapeutic Targeting of Metabolism in Leukemia and Lymphoma

Maximilian Stahl, Zachary D. Epstein-Peterson and Andrew M. Intlekofer

Non-Hodgkin Lymphomas: Malignancies Arising from Mature B Cells Jennifer Shingleton, Jie Wang, Carolyn Baloh, et al.

MAP-Kinase-Driven Hematopoietic Neoplasms: A Decade of Progress in the Molecular Age Rikhia Chakraborty, Omar Abdel-Wahab and Benjamin H. Durham

Mouse Models in the Study of Mature B-Cell Malignancies Laura Pasqualucci and Ulf Klein

Mouse Models of Myeloid Malignancies Faisal Basheer and George Vassiliou

Epigenetic Mechanisms in Leukemias and Lymphomas

Cihangir Duy, Wendy Béguelin and Ari Melnick

The Biology of B-Progenitor Acute Lymphoblastic Leukemia

Kathryn G. Roberts and Charles G. Mullighan

RNA Regulators in Leukemia and Lymphoma Camila Prieto and Michael G. Kharas
Biological and Translational Considerations regarding the Recent Therapeutic Successes and Upcoming Challenges for Multiple Myeloma Constantine S. Mitsiades

Biology and Molecular Pathogenesis of Mature T-Cell Lymphomas José R. Cortés and Teresa Palomero

The Role of Somatic Mutations in Acute Myeloid Leukemia Pathogenesis Ashwin Kishtagari and Ross L. Levine

Chronic Lymphocytic Leukemia Nicholas Chiorazzi, Shih-Shih Chen and Kanti R. Rai

Normal Hematopoiesis Is a Balancing Act of

Self-Renewal and Regeneration Oakley C. Olson, Yoon-A Kang and Emmanuelle Passegué

Impact of Genetics on Mature Lymphoid

Leukemias and Lymphomas

Nathanael G. Bailey and Kojo S.J. Elenitoba-Johnson

Epidemiology and Etiology of Leukemia and

Lymphoma Jordan A. Baeker Bispo, Paulo S. Pinheiro and Erin K. Kobetz

Clonal Hematopoiesis and Premalignant Diseases Justin Kaner, Pinkal Desai, Nuria Mencia-Trinchant, et al.

For additional articles in this collection, see http://perspectivesinmedicine.cshlp.org/cgi/collection/ 